\title{
Investigating regional groundwater flow systems in baja california central desert region
}

\begin{abstract}
In Northern Baja California, environmental conservation may not be fully accomplished in the absence of a clear understanding of key factors controlling and protecting biodiversity. Groundwater is an environmental agent triggering the presence of a wide range of arid ecosystems; therefore, any sustainable development in the region has to maintain a balance between environmental, social and economical benefits. The present study has placed a great emphasis on the understanding and distribution of groundwater flow systems, and their environmental interactions in the protected area of the Valle de Los Círios, using physical-chemical and isotope methods. Results show the presence of three groundwater groups portraying contrasting flow systems conditions. Analyzed samples have been classified as fresh-brackish, and thermal alkaline groundwater as suggested by $\mathrm{pH}$, temperature and $\mathrm{TDS}$. The $\mathrm{Br} / \mathrm{Cl}$ ratio in most samples was close to the ocean molar value $\left(1.5 \times 10^{-3}\right)$ indicating the importance of marine aerosol fraction in the recharged waters; however, $\mathrm{Mg} / \mathrm{Cl}, \mathrm{Na} / \mathrm{Cl}, \mathrm{Ca} / \mathrm{Cl}, \mathrm{SO}_{4} /$ $\mathrm{Cl}$ and $\mathrm{Cl} / \mathrm{HCO}_{3}+\mathrm{Cl}$ ratios were significantly different to those of seawater mixing conditions. Dominant ions ( $\mathrm{Na}, \mathrm{Ca}$ and $\mathrm{Cl})$, chemical age proxies $(\mathrm{Li})$, and $\delta^{18} \mathrm{O}$ suggest waters with long residence time, with the possibility of been recharge during the late glacial period. Thermal ground water shows low minor and trace element content and exhibits the dominance of Na-plagioclase hydrolysis; their low levels of $\mathrm{Sr}$ and Ba suggest negligible contact with calcareous rocks and their estimated temperature at depth $\left(80\right.$ to $\left.100^{\circ} \mathrm{C}\right)$ and TDS suggest groundwater has travelled through fractured media. This introduction study suggests that desertic species in Valle de Los Cirios are highly sustained by groundwater of local and intermediate flows.
\end{abstract}

Keywords: Geochemical analyses, Stable Isotopes, Flow systems, Valle los Círios, Northern Baja California, Mexico
Volume 2 Issue I - 2018

\author{
Samira Ouysse', Elisabet VWehncke², José \\ Joel Carrillo Rivera ${ }^{3}$ \\ 'National Council of Science and Technology, Autonomous \\ University of Zacatecas, México \\ ${ }^{2}$ Department of Biodiversity and Conservation, Autonomous \\ University, México \\ ${ }^{3}$ Department of Physical Geography, Institute of Geography, \\ National Autonomous University of Mexico, México
}

Correspondence: Samira Ouysse, National Council of Science and Technology,Autonomous University of Zacatecas, México, México, Email souysse@conacyt.mx

Received: February 0I, 2018 | Published: February 27, 2018

\section{Introduction}

The Baja California peninsula has long been recognized as a hotspot for plant richness and endemism and has been the subject of 14 decrees as protected areas. ${ }^{1}$ However, its extraordinary and unique diversity is not adequately protected by the existing protected areas protocols. ${ }^{1}$ In the absence of perennial surface-water sources, any economic development in the area will depend solely on groundwater. It is therefore substantial to establish a new approach that broads the goal of biodiversity protection. Various studies ${ }^{2-5}$ have shown the groundwater role in controlling ecological functioning and scatter vegetation, especially in its discharge zones. Thus, hydrological processes are the main controlling factor in the ecological function and variation of uncultivated lowlands. ${ }^{2}$ These processes are related to the evolving hierarchy of groundwater flow systems. Since the encounter of the flow systems concept, ${ }^{6}$ the hydrogeology's basic paradigm has shifted from confined flow in aquifer units to crossformational-flow in drainage basins. ${ }^{7}$ Consequently, groundwater has been recognised as a fundamental geologic agent, generating and modifying natural processes and phenomena of scientific, practical and economic interest. ${ }^{7}$ The distribution of vegetation cover in response to nutrient and moisture conditions is generated by groundwater inflow and out-flow; water level fluctuation; negative water-balance in recharge zones, and water surplus in discharge zones (wetland); anionic changes with depth and along groundwater flow systems; negative and positive geothermal anomalies, are considered to be the main indicators of groundwater flow hierarchy, among others. ${ }^{7}$ The use of physical-chemical hydrogeological approaches in parallel with a wide range of geological settings and field parameters remain a cornerstone in understanding, delineating and defining groundwater flow patterns and in establishing regional flow models. Several studies $^{8-11}$ have shown the positive correlation between groundwater residence time and the concentration of certain major and trace elements as Li. Nevertheless, groundwater age determination remains a challenge when it comes to: the use of plug-flow and binary mixing models, the interpretation of environmental tracers in fractured rocks, the use of radiocarbon in environment dominated by volcanic rocks, and the age sensitivity to vertical heterogeneity. ${ }^{12}$ For this purpose, it is fundamental to understand the behaviour of chemical and environmental tracers in their geological, morphological, and climate contexts. In the Central Desert region of Baja California, studies dedicated to regional understanding of groundwater flow functioning are infrequent; development and population growth is scarce so the availability of groundwater data is limited to scattered springs and few dug wells. Therefore, due to the scarcity of hydraulic and chemical data this work aims to meet the following objectives under the Groundwater Flow System methodology:

i. To analyse groundwater-rock interaction processes using physical-chemical and isotope methods

ii. To chemically differentiate groundwater flow patterns and distribution of discharge zones by understanding the theoretical hydrogeological presence of regional, intermediate and local flows within the ecosystem of the Baja California region. 


\section{Study region}

The study region is located in the northern part of Baja California peninsula, in the Playas de Rosarito District; it extends over a surface of $6,000 \mathrm{~km}^{2}$ (Figure 1), between latitude $28^{\circ} 0$ ' $49.368^{\prime \prime}, 28^{\circ} 59^{\prime} 28.752^{\prime \prime}$ $\mathrm{N}$ and longitude $112^{\circ} 44^{\prime} 45.52^{\prime \prime}, 114^{\circ} 26^{\prime} 54.096^{\prime \prime} \mathrm{W}$. The region is enclosed between the Libertad and San Borja mountains range and it includes the protected area of Valle Los Círios with 164 endemic species in a distinct arid environment. The peninsula is covered with 20 different types of climate; from very arid to temperate. ${ }^{13}$ Most of Baja California has a mean annual temperature above $18{ }^{\circ} \mathrm{C}$ and a mean annual rainfall lower than $200 \mathrm{~mm}$. The highest rainfall (500$700 \mathrm{~mm}$ ) occurs in the highlands of Sierras of San Pedro Mártir and La Laguna, in both latitudinal extremes of the peninsula. ${ }^{1}$

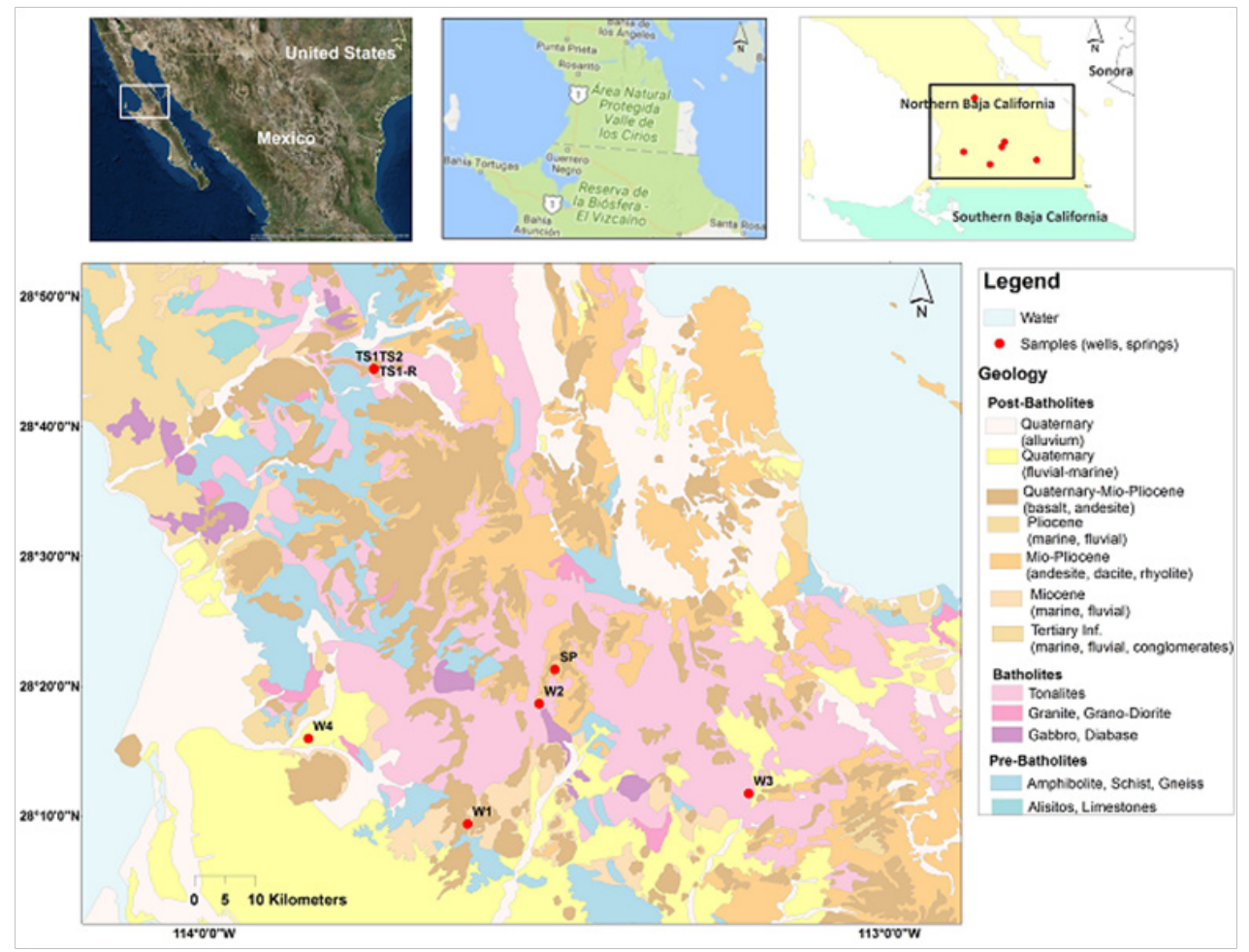

Figure I Map showing outcropping geological formations and location of the study region within the Northern Baja California Peninsula.

\section{Geological setting}

The geological substratum that supports the rich marine and terrestrial biodiversity and distinctive ecological niches in the Gulf of California region is predominantly composed of granitic and volcanic rocks, as well as sediments derived from these igneous rocks of various ages. ${ }^{14}$ The rocks of Baja California (Figure 1) contain the record of two geologic revolutions; the Mid-Mesozoic event which occurred from Jurassic through Middle Cretaceous time and is documented by volcanic strata and the emplacement of pervasive granitic rock; the second, the Mid-Cenozoic event which involved the accumulation of a wide variety of volcanic rocks, a granite emplacement, and the creation of the Gulf of California. ${ }^{15}$ These two events divide the geological history of Baja California into significant intervals; what occurred before the culminating granitic emplacements of Middle Cretaceous time is referred to as "pre-batholithic"; everything thereafter, as "post-batholithic". Along the western shore of Baja California there is a belt consisting of Mesozoic volcanic and volcano-clastic rocks (Figure 1). Cretaceous intrusions in the western Peninsular Ranges Batholith (PRB) were emplaced about ca.140 Ma. ${ }^{16,17}$ Compositions range from gabbro to rare granite that includes low $\mathrm{K}$ quartz gabbro to quartz diorite. The north-western PRB includes gneiss-granite in a belt that extends at $150 \mathrm{~km}$ northbound, beyond the international
USA border. ${ }^{18}$ In the central part of the peninsula there is a belt of metamorphosed shale and sandstone (Figure 1). On the eastern side there is a belt that contains a great variety of Palaeozoic metasedimentary rocks, including those derived from carbonates rocks, metamorphosed shale, sandstone, conglomerate, and limestone, with some volcanic rocks, and weakly metamorphosed pebbly mudstone, wacke, quartzite, thick carbonate units, banded chert, marlstone, and coarse arkose ${ }^{15}$ (Figure 1). This eastern part includes mid-cretaceous intrusions that occurred between ca.105 and ca.90. ${ }^{16}$ The eastern PRB varies in composition from gabbro to rare granite but are dominated by tonalite-trondhjemite-granodiorite or biotite tonalite..$^{15,17-21}$ These rocks are lower in dark minerals and potash feldspar (low in $\mathrm{K}_{2} 0, \mathrm{FeO}$, and $\mathrm{MgO}$, and high in $\mathrm{SiO}_{2}$ and $\mathrm{Al}_{2} \mathrm{O}_{3}$ ) than the rocks of the western part of the batholith. ${ }^{22}$ Marine Palaeocene and early Eocene strata occur in many places along and south from the Western Cape territory of Baja California. ${ }^{23,24}$ The marine Palaeocene and Eocene strata are deltaic or near-shore deposits. There are also extensive deposits of non-marine, post-batholithic, pre-volcanic sedimentary rocks of undetermined age, ${ }^{15}$ The marine Pliocene deposits of southern and northern Baja California are littoral sandstone and conglomerate derived from the basement rock and older sedimentary strata immediately to the east. The Quaternary (Pleistocene-Holocene) deposits are characterized by alluvial, marine and non marine deposits (Figure 1). 


\section{Methodology}

The methodology adopted in this study highlights the role of groundwater as a geologic agent by applying the gravity driven flow concept $t^{6,7,25}$ which differentiates the presence of three major type of flow systems (local, intermediate, regional), based on the physicalchemical and environmental isotopes evolution, and regional natural indicators (discharge zones, type of soil and vegetation). Eight groundwater samples were collected in November 2013 from wells and springs at the lower parts of several canyons in the Libertad mountain range, running deep into the Central Desert region and constituting one of the most interesting transition and controversial zones for vegetation experts. ${ }^{26}$ The Libertad mountain range is a major transition between two desert regions, the Central Desert towards the north, and the Vizcaíno Desert to the south and is included in the protected area of Valle de Los Cirios. ${ }^{26}$ Major difficulties were encountered during sampling due to the lack of access to operational wells in the area of El Arco, the presence of abandoned wells, and the absence of monitoring wells. Operational wells were found to be sealed and lithology-logs were absent. When water outlet allowed, water sampling was carried out using a flow-cell to avoid contact between groundwater and atmosphere. Spring-waters were collected by directly dipping the sampling bottles and submerging electrodes. Physical-chemical parameters like temperature, electrical conductivity (EC), $\mathrm{pH}$,redox potential (Eh), dissolved oxygen (DO), and alkalinity were measured in situ. Equipment and electrodes used were calibrated accurately against known standards before and during related field measurements. Polyethylene bottles of $60 \mathrm{ml}$ were presterilized by $10 \% \mathrm{HNO}_{3}$ immersion and distilled water wash to avoid contamination; during sampling they were rinsed three times with sampled water. Samples were filtered using a $0.45 \mu \mathrm{m}$ cellulose acetate membrane. The carbonates alkalinity was determined using a digital titrator acid-base titration $\left(\mathrm{H}_{2} \mathrm{SO}_{4}, 1.6 \mathrm{~N}\right)$. The $\mathrm{HCO}_{3}$ concentration was deduced using Gran method. Sampled groundwater was analysed for anions, cations, trace elements, nitrates and stable isotopes $\left(\delta^{2} \mathrm{H}, \delta^{18} \mathrm{O}\right)$. Cation samples were acidified with high purity concentrated $\mathrm{HNO}_{3}$ to reach samples a $\mathrm{pH} \approx 2$. For nitrate samples, sulphuric acid was added. All samples were preserved at low temperature $\left(\approx 4^{\circ} \mathrm{C}\right)$. Chemical and isotope analyses were conducted in the Actlabs Group, Canada and in the Laboratory of Isotope Geochemistry, University of Arizona, Tucson (USA), respectively. Major and minor cations were analysed using the inductively coupled plasma-mass spectrometry (ICP-MS),

Table I Physical and chemical analyses of groundwater samples and the anions $\left(\mathrm{F}, \mathrm{Cl}, \mathrm{NO}_{3}, \mathrm{NO}_{2}, \mathrm{Br}, \mathrm{SO}_{4}\right)$ analyses were performed using Ion Chromatography system (IC). Geochemical speciation modelling and saturation index calculations were carried out using the PHREEQC code. ${ }^{27}$

\section{Results and discussions}

The interpretation of the hydro-chemical results could be affected by uncertainty on data reliability, to ensure the quality of carried analyses, the ionic balance was calculated and duplicate sample was used. Error values were from $0.08 \%$ to $7.81 \%$ (Table 1); suggesting good accuracy of the given analyses. Groundwater in the sampled wells and springs could be initially classified from fresh to brackish according to total dissolved solids (TDS) values $(307-3,002 \mathrm{mg} / \mathrm{L}$ ). The salinity of domestic wells $\left(\mathrm{W}_{1}, \mathrm{~W}_{2}, \mathrm{~W}_{4}\right)$, and spring $\left(\mathrm{S}_{\mathrm{p}}\right)$ (Table 1) was indicated by the importance of TDS and the ionic strength, which ranges between 0.01 and $0.06 \mathrm{M}$; this implies that cations and anions are more soluble in these waters due to the importance of electrostatic interactions among ions. In general, $\mathrm{Na}$ and $\mathrm{HCO}_{3}-\mathrm{Cl}$ are the dominant ions, and the groundwater composition can be displayed as follows: $\mathrm{Na}>\mathrm{Ca}-\mathrm{Cl}>\mathrm{HCO}_{3}$ for $\mathrm{W}_{1}, \mathrm{Na}>\mathrm{Ca}-\mathrm{Cl}$ for $\mathrm{W}_{2} \& \mathrm{~W}_{4}, \mathrm{Na}>\mathrm{Ca}-$ $\mathrm{HCO}_{3}$ for $\mathrm{S}_{\mathrm{p}}, \mathrm{Ca}-\mathrm{Na}-\mathrm{HCO}_{3}$ for $\mathrm{W}_{3} \& \mathrm{Na}-\mathrm{Cl}-\mathrm{HCO}_{3}$ for $\mathrm{TS}_{1}, \mathrm{TS}_{2} \& \mathrm{TS}_{1}-\mathrm{R}$ $\left(=T S_{1}\right.$ duplicate) (Table 1). The relation between lithology and groundwater composition is represented in a Piper diagram (Figure 2 ), in which the presence of three major water groups may suggest different lithology, residence time and weathering conditions (Grp1: $\mathrm{TS}_{1}, \mathrm{TS}_{2} \& \mathrm{TS}_{1}-\mathrm{R} ;$ Grp2: $\mathrm{W}_{1}, \mathrm{~W}_{2}, \mathrm{~W}_{4} \& \mathrm{Grp} 3: \mathrm{W}_{3} \& \mathrm{~S}_{\mathrm{P}}, \quad\left(S_{W}\right.$ : seawater composition in Bahia Concepcion). ${ }^{28}$ The anion content depicts the importance in the progress of water-rock interaction. Group 2 represents the more evolved waters as compared to Grp3 and Grp1. The Grp1 shares a salt-fresh water mixture, whereas the fresh water in Grp3 had a cation-exchange signature. According to the concentration of TDS and $\mathrm{Cl}$, waters in Grp2 can be classified as water having an intensive geochemical interaction with the material of the aquifer unit. The igneous and metamorphic rock types of the study region are well represented in the groundwater cation chemistry which suggest a chemical weathering of ferromagnesian (basalt) and feldspars rich plagioclase rocks (tonalite, granite, granodiorite). The groundwater in the study region was initially classified in three groups; in which a simple mixture (mixing line) among samples is unlikely to occur due to distinctive physical-chemical ( $\mathrm{pH}, \mathrm{T}, \mathrm{TDS}, \delta^{2} \mathrm{H}, \delta^{18} \mathrm{O}$ ), geological, and recharge conditions (altitude, climate) characteristics among samples.

\begin{tabular}{|c|c|c|c|c|c|c|c|c|c|c|c|c|c|c|c|c|c|c|c|c|c|c|c|}
\hline Sample ID & $\begin{array}{l}\text { Sampling } \\
\text { Date }\end{array}$ & $\begin{array}{l}\text { Water } \\
\text { type }\end{array}$ & $x(m)$ & $Y(m)$ & $\begin{array}{l}\text { Elevation } \\
\text { m(ass) }\end{array}$ & $\begin{array}{l}{ }^{\top} \\
\text { ("C) }\end{array}$ & $\mathrm{pH}$ & $\begin{array}{l}\mathrm{Eh} \\
(\mathrm{mV})\end{array}$ & $\begin{array}{l}\text { Do } \\
\text { (mgl) }\end{array}$ & $\begin{array}{l}\text { EC } \\
(\mu \mathrm{s} \\
\mathrm{cm})\end{array}$ & $\begin{array}{l}\text { TDS } \\
\text { (mgIl) }\end{array}$ & $\begin{array}{l}\mathrm{ca}_{(\mathrm{mg} /)} \\
\left({ }^{2}\right.\end{array}$ & $\underset{(\mathrm{mgl})}{\mathrm{Mg}}$ & $\underset{\mathrm{mg}}{\mathrm{Na}}$ & $\underset{\mathrm{mg} / \mathrm{k}}{\mathrm{k}}$ & $\begin{array}{l}\mathrm{Cl}_{(\mathrm{mg} /)}\end{array}$ & $\begin{array}{l}\text {-Alkalinity } \\
(\mathrm{mgll})\end{array}$ & $\begin{array}{l}\mathrm{HCO}^{\mathrm{H}} \\
\text { (mgll) }\end{array}$ & $\begin{array}{l}\mathrm{co}_{3} \\
(\mathrm{mgll})\end{array}$ & $\begin{array}{l}\text { so, } \\
\text { (mgl) }\end{array}$ & $\begin{array}{l}\mathrm{NO}_{\text {, (as }} \\
\mathrm{N} \text { (mgll) } \\
\text { (mgl) }\end{array}$ & $\begin{array}{l}\mathrm{NO}_{3} \\
\text { (as N } \\
\left(\mathrm{mg}^{\prime \prime}\right)\end{array}$ & ${ }_{\%}^{18+4+1}$ \\
\hline $\begin{array}{l}\text { Detection } \\
\text { limit }\end{array}$ & & & & & & & & & & & & 700 & 2 & 5 & 30 & 0.03 & & & & 0.03 & 0.01 & 0.01 & \\
\hline$w_{1}(D)$ & 261112013 & $\begin{array}{l}\mathrm{Na}_{2}>\mathrm{C}_{2}>\mathrm{Mg}_{\mathrm{g}} \\
\mathrm{C}>\mathrm{HCO}-\end{array}$ & -12648000 & 3268596.473 & 261 & 23.4 & 7.16 & 105 & 4.4 & 1547 & 1037.69 & 111.0 & 40.0 & 169 & 6.75 & 388 & 201.11 & 244.53 & & 46.1 & $<0.05$ & 2.45 & 1.20 \\
\hline $\mathbf{w}_{2}(\mathrm{D})$ & 271112013 & $\begin{array}{l}\mathrm{N}_{\mathrm{a}}>\mathrm{M}_{\mathrm{g}}>\mathrm{Ca}- \\
\mathrm{Cl}\end{array}$ & -12636000 & 3288159.875 & 448 & 25.6 & 6.78 & 116 & 3.6 & 4590 & 300228 & 273.0 & 188.0 & 453 & 12.2 & 1320 & 423.44 & 516.28 & & 195.0 & $<0.3$ & 0.70 & 0.72 \\
\hline $\mathbf{S P}\left(\mathrm{Sp}_{\mathrm{p}}\right)$ & $27111 / 2013$ & $\begin{array}{l}\mathrm{Na}>\mathrm{Ca}>\mathrm{Mg}- \\
\mathrm{HCO}>>\mathrm{Cl}\end{array}$ & -12633000 & 3293738.581 & 577 & 20.4 & 6.96 & -40 & 11.3 & 1488 & 997.49 & 82.2 & 43.1 & 144 & 5.93 & 173 & 403.28 & 49.04 & & 18.0 & $<0.04$ & $<0.04$ & 270 \\
\hline$w_{3}(D)$ & 291112013 & $\begin{array}{l}\mathrm{C}_{a}>\mathrm{Na}_{\mathrm{N}}>\mathrm{Mg}- \\
\mathrm{HCO}>\mathrm{M}>\mathrm{Cl}\end{array}$ & -12602000 & 3273560.096 & 505 & 23.5 & 7.22 & 173 & 27 & 495 & 310.23 & 36.7 & 10.6 & 33.7 & 5.91 & 32.5 & 128.48 & 155.79 & & 11.0 & $<0.02$ & 4.64 & 0.66 \\
\hline$W_{4}($ D) & $29111 / 2013$ & $\mathrm{Na}_{\mathrm{C}}>\mathrm{C}_{2}>\mathrm{Mg} \mathrm{g}$ & -12673000 & 3282495.712 & 81 & 20.8 & 7.02 & 87 & 1.9 & 2310 & 1504.04 & 147.0 & 75.1 & 244 & 4.86 & 602 & 227.87 & 277.66 & & 126.0 & $<0.1$ & 2.02 & 0.08 \\
\hline
\end{tabular}


Table Continued...

\begin{tabular}{|c|c|c|c|c|c|c|c|c|c|c|c|c|c|c|c|c|c|c|c|c|c|c|c|}
\hline Sample ID & $\begin{array}{l}\text { Sampling } \\
\text { Date }\end{array}$ & $\begin{array}{l}\text { Water } \\
\text { type }\end{array}$ & $x(m)$ & $Y(m)$ & $\begin{array}{l}\text { Elevation } \\
\text { m(asl) }\end{array}$ & $\begin{array}{l}\left.{ }^{\mathrm{T}} \mathrm{C}\right) \\
\left.{ }^{\mathrm{C}}\right)\end{array}$ & $\mathrm{pH}$ & $\begin{array}{l}E^{E h} \\
(m \mathrm{~V})\end{array}$ & $\begin{array}{l}\text { Do } \\
\left(\mathrm{mg}^{\prime \prime}\right)\end{array}$ & $\begin{array}{l}\text { EC } \\
\text { ( } \mathrm{s} \\
\mathrm{cm})\end{array}$ & $\begin{array}{l}\text { TDS } \\
(\mathrm{mgll})\end{array}$ & $\begin{array}{l}\mathrm{ca} \\
(\mathrm{mg} /)\end{array}$ & $\begin{array}{l}\mathrm{Mg}_{\mathrm{g}} \\
\left(\mathrm{mg} \mathrm{g}^{\prime \prime}\right)\end{array}$ & $\begin{array}{l}\mathrm{Na} \\
\mathrm{mgl}\end{array}$ & $\begin{array}{l}{ }_{\mathrm{mg}} \\
\mathrm{mg}\end{array}$ & $\begin{array}{l}\mathrm{Cl} \\
(\mathrm{mg} / 1)\end{array}$ & $\begin{array}{l}\text { "Alkalinity } \\
\text { (mgll) }\end{array}$ & $\begin{array}{l}\mathrm{HCO}_{3} \\
\text { (mgll) }\end{array}$ & $\begin{array}{l}\mathrm{Co}_{3} \\
\left(\mathrm{mg} \mathrm{g}^{\prime \prime}\right)\end{array}$ & $\begin{array}{l}\text { so, }^{\prime} \\
\text { (mgll) }\end{array}$ & $\begin{array}{l}\mathrm{NO}_{2} \text { (as } \\
\text { N) } \\
(\mathrm{mg} / 1)\end{array}$ & $\begin{array}{l}\mathrm{NO}_{3} \\
\text { (as N } \\
\text { (mglil) }\end{array}$ & 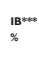 \\
\hline 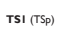 & 30/11/2013 & $\begin{array}{l}\text { Na-Cl- } \\
\text { HCO3 }\end{array}$ & -12663000 & 33426616.458 & 428 & 34.4 & 9.31 & -217 & 3.5 & 512 & 304.99 & 4.0 & 0.068 & 101 & 1.15 & 78.8 & 70.19 & 61.7 & 9.9 & 26.6 & $<0.02$ & $<0.02$ & 5.85 \\
\hline TS2 (TSp) & 30111/2013 & $\begin{array}{l}\mathrm{Na} \\
\mathrm{HCO} \cdot \mathrm{Cl}\end{array}$ & -12663000 & 3342570.611 & 436 & 27.8 & 9.50 & -3 & 3.9 & 512 & 326.77 & 4.0 & 0.048 & 101 & 1.18 & 78.9 & 90.19 & 80.5 & 13.9 & 27.1 & $<0.02$ & $<0.02$ & 0.61 \\
\hline $\begin{array}{l}\text { TSS-R R(RP. } \\
T S S I)\end{array}$ & 30/11/2013 & $\begin{array}{l}\mathrm{Na}-\mathrm{Cl} \\
\mathrm{HCO} 3\end{array}$ & -12663000 & 3342616.458 & ${ }^{428}$ & 34.4 & 9.31 & -217 & 3.5 & 512 & 307.83 & 4.0 & 0.044 & 105 & 1.14 & 78.3 & 70.19 & 61.7 & 9.9 & 26.7 & $<0.02$ & $<0.02$ & 7.81 \\
\hline
\end{tabular}

D, Domestic well; Sp, Spring;TSp, Thermal Spring; Rp, Replicate; *TDS, Calculated with Aquachem; **, CaCO ; $§$, Field Measured; EC, Electrical Conductivity; IB***, Error ionic balance

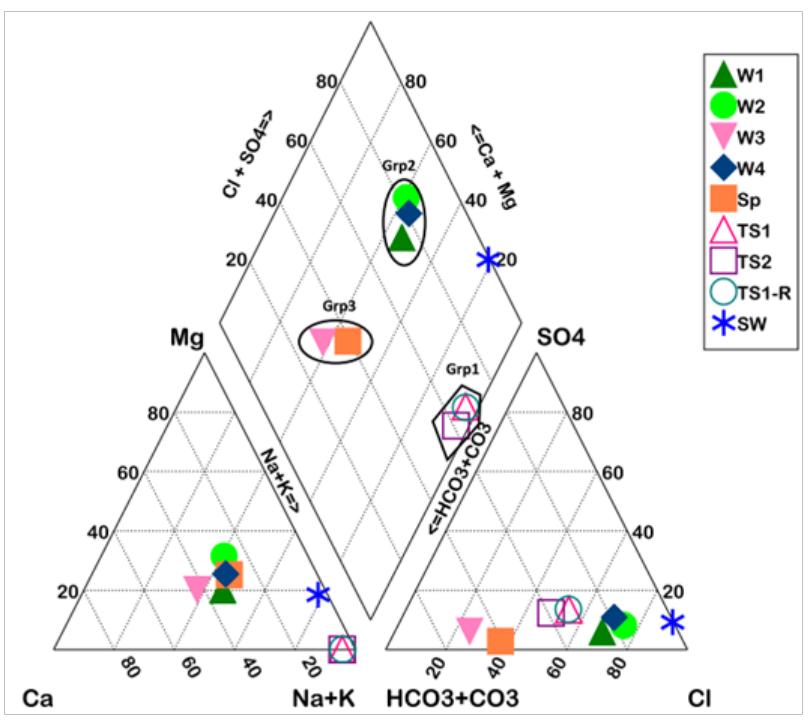

Figure 2 Piper diagram for groundwater samples.

\section{Cation-anion concentration and mineral solubility}

Major ion composition and ionic ratios can act as a track-record of water-rock interaction during flow ${ }^{29}$ the concentrations of some major ions and ionic ratios were plotted against $\mathrm{Cl}$, which is regarded as conservative. The $\mathrm{Na}$ vs $\mathrm{Cl}$ shows that the samples are relatively placed below or above the halite dissolution line (Figure $3 \mathrm{~A}$ ). The $\mathrm{Na} / \mathrm{Cl}$ ratio $(>1)$ (Table 3), show that the increases of Na content in Grp1 (TS, $\mathrm{TS}_{2}$ and $\left.\mathrm{TS}_{1}-\mathrm{R}\right)$ reflects a progressive reaction with plagioclase feldspar. Despite its relatively slow weathering process, plagioclase feldspar (albite-anorthite) consumes acidity to produce low temperature clay mineral ${ }^{30}$ as a result, the $\mathrm{pH}$ in Grp1 increased and the solubility of calcite decreased; which instantly has lowered the $\mathrm{HCO}_{3} / \mathrm{Cl}$ and $\mathrm{Ca} /$ $\mathrm{Na}$ ratios (Table 3 ). In addition to the precipitation of calcite, high $\mathrm{Na}$ concentration could be related to cation-exchange and high ionic mobility of $\mathrm{Na}$ with respect to $\mathrm{Ca} .{ }^{31}$ The $\mathrm{Sr} v s \mathrm{Cl}$ (Figure 3D) shows an increase of $\mathrm{Sr}$ with increasing $\mathrm{Cl}$ for waters in Grp2 and Grp3 $\left(W_{2}>W_{1}>W_{4}>S P>W_{3}\right.$, respectively). The $\mathrm{Sr}$ content shows a general correlation with $\mathrm{Ca}$ and $\mathrm{SO}_{4}$, especially at higher concentrations, indicating association with gypsum/anhydrite. ${ }^{32}$ However, the $\mathrm{Sr} / \mathrm{Ca}$ ratios $\left(2-7 \times 10^{-3}\right)$ (Table 3$)$ are in the range expected from water draining plutonic, volcanic and metamorphic rocks. ${ }^{33}$ The molar ratio of $\mathrm{Br} / \mathrm{Cl}$ may be used to characterize the source and evolution of dissolved $\mathrm{Cl}$ as marine and evaporite sources have characteristic signatures. ${ }^{34,35}$ The $\mathrm{Br} v s \mathrm{Cl}$, (Figure 3G) shows an increase of $\mathrm{Br}$ with increasing $\mathrm{Cl}$ content, and $\mathrm{Br} / \mathrm{Cl}$ ratio (Table 3 ) reveals a relatively constant value for most samples ( 1.2 to $\left.1.7 \times 10^{-3}\right)$ suggesting a conservative behaviour of $\mathrm{Br} / \mathrm{Cl}$ during water-rock interaction. These values are close to the ocean constant molar ratio $\left(1.5 \times 10^{-3}\right)$, suggesting that recharged waters are reflecting the marine aerosol ratio. ${ }^{8}$ Consequently, recharge seems to be dominantly affected by the coastal atmospheric deposition along the western part; as towards the east the continental component becomes more prominent. Thus, in Bahia Conception location (Gulf of California), ${ }^{28}$ shallow seawater presented higher $\mathrm{Br} / \mathrm{Cl}$ molar ratio $\left(\approx 5 \times 10^{-3}\right)$ due probably to the sink of $\mathrm{Cl}$ as result of evaporates precipitation. In addition, the importance of $\mathrm{Br} / \mathrm{Cl}$, may involve the alteration of andesitic rocks; which present a $\mathrm{Br} / \mathrm{Cl}$ ratio ranging from 1.5 to $6.3 \times 10^{-3} .{ }^{36} \mathrm{In}$ general, samples composition is unlikely to be a result of mixing with seawater, with molar ratios of $\mathrm{Mg} / \mathrm{Cl}$, $\mathrm{Na} / \mathrm{Cl}, \mathrm{Ca} / \mathrm{Cl}, \mathrm{SO}_{4} / \mathrm{Cl}$ and $\mathrm{Cl} / \mathrm{HCO}_{3}+\mathrm{Cl}$ (Table 3 ) being significantly different from those of seawater. Sample $\mathrm{W}_{3}$ shows a more depleted $\mathrm{Br} / \mathrm{Cl}$ ratio $\left(0.8 \times 10^{-3}\right)$ as compared to the other samples; suggesting dissolution or addition of $\mathrm{Cl}$ from an evaporate source; ${ }^{35}$ or loss of $\mathrm{Br}$ from the fluids to diagenetic solids. ${ }^{36} \mathrm{In} \mathrm{Grp} 2, \mathrm{Mg} / \mathrm{Ca}$ increases with $\mathrm{Cl}$ increase (Figure $3 \mathrm{~B}$ ); however, the $\mathrm{Mg} / \mathrm{Ca}$ ratio (Table 3) increase occurs independently of $\mathrm{Cl}$ in the unevolved fresh-waters of Grp3. The concentration of $\mathrm{Li}$ and $\mathrm{F}$ correlates positively with $\mathrm{Cl}$ increase, suggesting the presence of evolving groundwater (Figure $3 \mathrm{~F} \& \mathrm{H}$ ). The $\mathrm{SO}_{4} v s \mathrm{Cl}$ (Figure 3C) shows a positive correlation; however, $\mathrm{NO}_{3} v s$ $\mathrm{Cl}$ (Figure 3I) shows a random distribution, suggesting that $\mathrm{SO}_{4}$ and $\mathrm{NO}_{3}$ patterns lack a relation to anthropogenic origin. The $\mathrm{Ca}$ as related to $\mathrm{HCO}_{3}$ and $\mathrm{SO}_{4}$ (Figure 4A\&B) show a nonlinear correlation along the gypsum and calcite dissolution lines; suggesting a different source of sulphide and $\mathrm{HCO}_{3}$ contents. The importance of $\mathrm{Ca}$, and relatively high $\mathrm{Ca} / \mathrm{Cl}$ ratio (Table 3 ) in samples $\mathrm{W}_{1}, \mathrm{~W}_{2}, \mathrm{~S}_{\mathrm{p}}, \mathrm{W}_{3} \& \mathrm{~W}_{4}$ may be explained by dissolution of $\mathrm{Na}-\mathrm{Ca}$ plagioclase, and calcite. The importance of $\mathrm{Cl}$ in samples $\mathrm{W}_{1}, \mathrm{~W}_{2}, \mathrm{~W}_{4}, \mathrm{TS}_{1}, \mathrm{TS}_{2} \& \mathrm{TS}_{1}-\mathrm{R}\left(\mathrm{HCO}_{3} / \mathrm{Cl}\right.$ $<1)$ may be related to $\mathrm{Cl}$ liberation to the fluid phase during alteration of Cl-bearing amphibole and biotite. The $\mathrm{Ca}+\mathrm{Mg} / \mathrm{HCO}_{3}$ ratio (Table 3) indicates the dominance of $\mathrm{Ca}$ and $\mathrm{Mg}$ in Grp2, which could be explained by the weathering of ferromagnesian silicates, $\mathrm{Ca}-\mathrm{Na}$ plagioclase and/or carbonates rocks. By contrast, waters in Grp1 and Grp3 show more $\mathrm{HCO}_{3}$ content which may be related to the weathering of Na-rich feldspars ( $\mathrm{Na} / \mathrm{Ca}+\mathrm{Mg}>40$ for $\mathrm{Grp} 1)$, and/or relative recent introduction of atmospheric $\mathrm{CO}_{2}$ into the system (Grp3) (Table 3). The concentration of $\mathrm{NO}_{3}$ is below the World Health Organization (WHO) maximum contaminant level (MCL) $(<5 \mathrm{mg} / \mathrm{l})$ and lacks correlation with DO values (Table 1); more oxygenated water shows low values of $\mathrm{NO}_{3}$. All chemical elements and compounds are at concentration below drinking water standards, except for total dissolved solids of samples $\mathrm{W}_{2}$ and $\mathrm{W}_{4}$. Dissolved oxygen shows values ranging from 1.9 to $11.3 \mathrm{mg} / 1$ (Table 1 ). These values are not representing the actual conditions at depth as water might be affected by the exposure to the atmosphere. The aqueous speciation calculation using Phreeqc (Table 4) shows that the $\mathrm{Fe}(\mathrm{II})$ species $\left(\mathrm{Fe}^{2+}, \mathrm{FeHCO}_{3}{ }^{+}, \mathrm{FeCO}_{3}^{+}\right)$are dominant in most samples. However, samples $\mathrm{TS}_{1}\left(\mathrm{TS}_{1}-\mathrm{R}\right.$ duplicate), and $\mathrm{TS}_{2}$ 
show the importance of insoluble $\mathrm{Fe}(\mathrm{OH})_{3}$ which explain the low concentration of dissolved Fe. For samples $\mathrm{W}_{1} \& \mathrm{~W}_{4}$ the concentration of dissolved oxygen was associated with high dissolved $\mathrm{Fe}$ and $\mathrm{Mn}$ (766 and $80 \mu \mathrm{g} / 1 ; 5.9$ and $11.5 \mu \mathrm{g} / \mathrm{l}$, respectively); this suggests that reducing conditions may be prevailing in the groundwater supplying these wells, as supported by negative Eh field measurements (Table 1). All samples are oversaturated with respect to goethite and hematite (Table 5) which may reflect the intensity of dehydration processes at surface. The concentration of $\mathrm{Fe}^{2+}$ in sample $\mathrm{W}_{1}$ seems to be controlled by siderite dissolution which provides more Fe-oxides under oxidizing conditions. Relative cation content in sampled groundwater suggests that Grp2 and Grp3 (Figure 2) are related to geological units similar in nature (granodiorite and tonalite) (Figure 1) while samples of Grp1 has travelled through contrasting geological units (basaltic, Mgandesite and meta-sedimentary rocks).
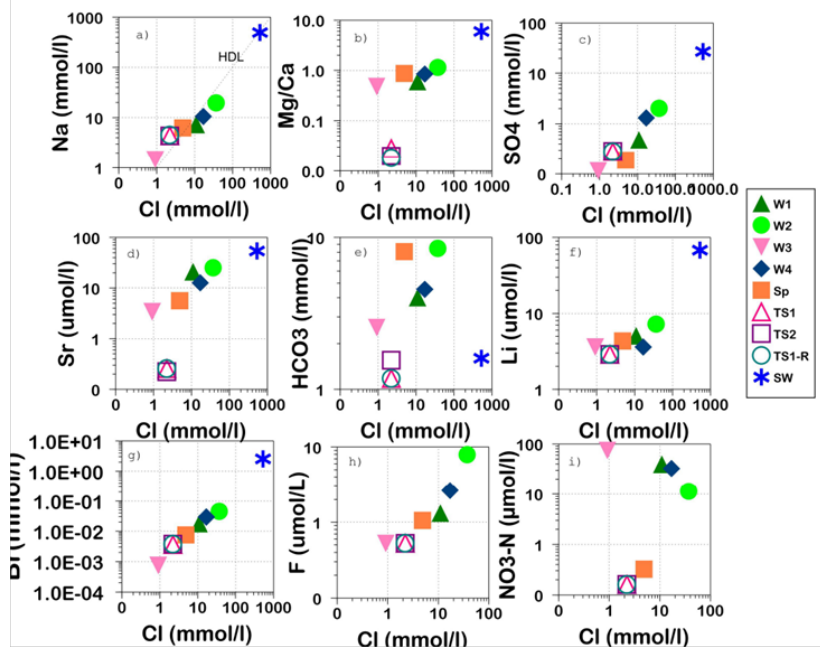

Figure 3 Logarithmic plots showing relationship of major and trace elements to $\mathrm{Cl}$; HDL, Halite Dissolution Line.
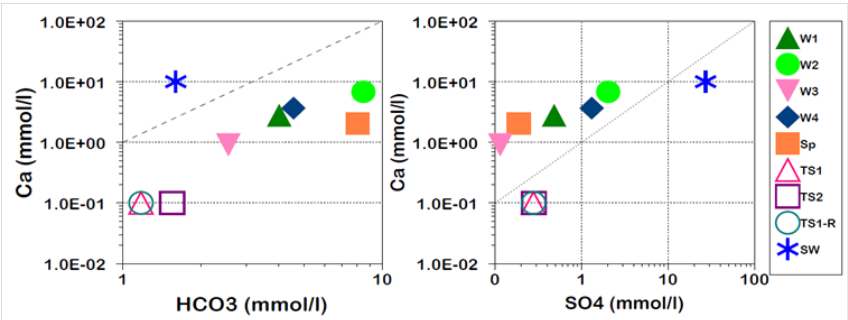

Figure 4 Logarithmic plots showing relationship between concentrations of chemical species:

A. $\mathrm{Ca}$ vs $\mathrm{HCO}_{3}$, dashed line shows the Calcite Dissolution Line

B. Ca vs $\mathrm{SO}_{4}$, dotted line shows the Congruent Gypsum Dissolution Line

\section{Minor and trace constituents in groundwater}

Minor and trace elements may be used as additional indicators of groundwater flow path and residence time. The important concentration of trace and minor constituents in Grp2 and Grp3, suggests a larger residence time as compared to thermal waters in Grp1, this argument appears to agree with the larger $\mathrm{Li}$ concentrations found between 35-
$50 \mu \mathrm{g} / 1$ for the former samples as referred to $20 \mu \mathrm{g} / 1$ for the thermal waters. The presence of other constituents suggests a conceptual support of different processes describing groundwater functioning. Total arsenic $\left({ }_{T} \mathrm{As}\right)$ in wells $\mathrm{W}_{1}, \mathrm{~W}_{2}, \mathrm{~W}_{3} \& \mathrm{~W}_{4}$, as well as in spring $\mathrm{S}_{\mathrm{p}}$, with a maximum value of $7.57 \mu \mathrm{g} / 1$ recorded in well $\mathrm{W}_{1}$ is below the suggested MCL $(10 \mu \mathrm{g} / \mathrm{l})$ for drinking water (Table 2). Despite the $\mathrm{pH}$ values which range between 6.78 and 7.22, the important value of ${ }_{T} A s$ in samples $\mathrm{W}_{1}, \mathrm{~W}_{2}, \mathrm{~S}_{\mathrm{p}}, \mathrm{W}_{3} \& \mathrm{~W}_{4}$ could be explained by the dominance of the anoxic form arsenite, As(III), which has more affinity for solids above $\mathrm{pH} 7-8$, and which its sorption decreases with increasing ionic strength. ${ }^{37}$ These results appear to confirm the origin of these samples derived from recharge-transit conditions as reported by Tóth. ${ }^{7,25}$ The concentration of $\mathrm{Pb}, \mathrm{Ni}, \mathrm{Hg}, \mathrm{Cd}, \mathrm{Cu} \& \mathrm{Cr}$ are below the proposed standard of the WHO (Table 2). Although, the concentration of $\mathrm{Zn}$ $(25.8-209.0 \mu \mathrm{g} / \mathrm{l})$ are below the permissible limit $(5.0 \mathrm{mg} / \mathrm{l})$; however, this metal seems to be concentrated in samples $\mathrm{W}_{1}, \mathrm{~W}_{2}, \mathrm{~W}_{3} \& \mathrm{~W}_{4}$ as compared to the rest of the samples suggesting extensive waterrock interaction. Uranium content in $\mathrm{W}_{1}, \mathrm{~W}_{2}, \mathrm{~S}_{\mathrm{p}}, \mathrm{W}_{3} \& \mathrm{~W}_{4}$ shows values above the WHO recommended limit $(2 \mu \mathrm{g} / \mathrm{l})$ (Table 2$)$. The concentration of $\mathrm{U}$ in samples $\mathrm{W}_{1}, \mathrm{~W}_{2}, \mathrm{~S}_{\mathrm{p}}, \mathrm{W}_{3} \& \mathrm{~W}_{4}$ with values from 4.0 to $21.5 \mu \mathrm{g} / 1$ shows a relative correlation with the changing of $\mathrm{HCO}_{3}$ content in the water. This is due to the positive association between $\mathrm{U}$ and $\mathrm{pH}$ in some environments, ${ }^{38}$ as the dissolved $\mathrm{HCO}_{3}$ increase the acidity by lowering the $\mathrm{pH}$, which increases $\mathrm{U}$ solubility (as $\mathrm{U}^{4+}$ and $\mathrm{UO}_{2}{ }^{2+}$ ). By contrast, thermal waters in Grp1 (TS \& $\mathrm{TS}_{2}$ ) show low values $(<0.005 \mu \mathrm{g} / \mathrm{l})$ which might be related to the $\mathrm{pH}$ and instability of carbonates complexes at high temperatures. In the study region, the origin of $\mathrm{U}$ in samples $\mathrm{W}_{1}, \mathrm{~W}_{2}, \mathrm{~S}_{\mathrm{p}}, \mathrm{W}_{3} \& \mathrm{~W}_{4}$ could be related to the leaching of sediments derived from granodiorite-tonalite formations under acidic conditions; groundwater remaining in contact with rocks for a long period of time have higher $U$ contents than those with short residence. ${ }^{37}$ Consequently, this residence time proxy suggests that $\mathrm{W}_{2}$ might be supplied with the oldest groundwater. Alike uranium, $\mathrm{V}$ concentrations in samples $\mathrm{W}_{1}, \mathrm{~W}_{2}, \mathrm{~S}_{\mathrm{p}}, \mathrm{W}_{3} \& \mathrm{~W}_{4}(14.7-89.9 \mu \mathrm{g} / \mathrm{l})$ appear to be correlated to the $\mathrm{pH}$ and the concentration of $\mathrm{HCO}_{3}$ in the solution (Tables 1\&2). The WHO has set a limit of $0.7 \mathrm{mg} / 1$ for Ba in drinking water. Samples $\mathrm{W}_{2}$ and $\mathrm{W}_{4}(184.0$ and $187.0 \mu \mathrm{g} / \mathrm{l}$, respectively) show the highest values of $\mathrm{Ba}$, which are equivalent to high concentration of $\mathrm{SO}_{4}$ (Tables 1\&2). Generally, concentration of $\mathrm{SO}_{4}$ in groundwater presents an important control on the concentration of dissolved $\mathrm{Ba}$ because of the low solubility of barite $\left(\mathrm{BaSO}_{4}, \mathrm{~K}=10^{-10}\right){ }^{39}$ The high $\mathrm{Ba}$ concentrations occur in groundwater that is anomalously depleted in dissolved sulphate. ${ }^{40}$ Samples $\mathrm{W}_{2}$ and $\mathrm{W}_{4}$ are saturated with respect to mineral barite (Table 5), suggesting that $\mathrm{Ba}$ concentration is controlled by the solubility of this mineral. However, in samples $\mathrm{W}_{1}$ and $\mathrm{S}_{\mathrm{p}}$, the concentration of $\mathrm{Ba}(80.5$ and $127 \mu \mathrm{g} / \mathrm{l}$, respectively) is accompanied by low levels of $\mathrm{SO}_{4}$ which could be related to the groundwater being subjected to anoxic conditions. ${ }^{40}$ The precipitation of barite can trigger the levels of other element which can represent health hazard at high concentration like radium (Ra). In Grpl ( $\mathrm{TS}_{1}, \mathrm{TS}_{2}$ and $\left.\mathrm{TS}_{1}-\mathrm{R}\right)$, high concentrations of tungsten (W) were recorded (Table 2). Many studies have shown that $\mathrm{W}$ can be toxic and carcinogenic. ${ }^{41}$ This high concentration in $\mathrm{TS}_{1}, \mathrm{TS}_{2}$ and $\mathrm{TS}_{1}-\mathrm{R}$ could be related to the important $\mathrm{pH}$ and the geothermal characteristics of groundwater. Waters in Grp1 are characterised by the presence of Gallium (Ga) and Germanium $(\mathrm{Ge})$, characteristic trace elements of geothermal waters. The Ge and Ga concentration are ranging from 3.2 to $3.75 \mu \mathrm{g} / 1$ and 1.2 to $1.25 \mu \mathrm{g} / 1$ (Table 2), respectively. 
Table 2 Trace, minor elements, and stable isotopes in groundwater samples (DL*: Detection limit)

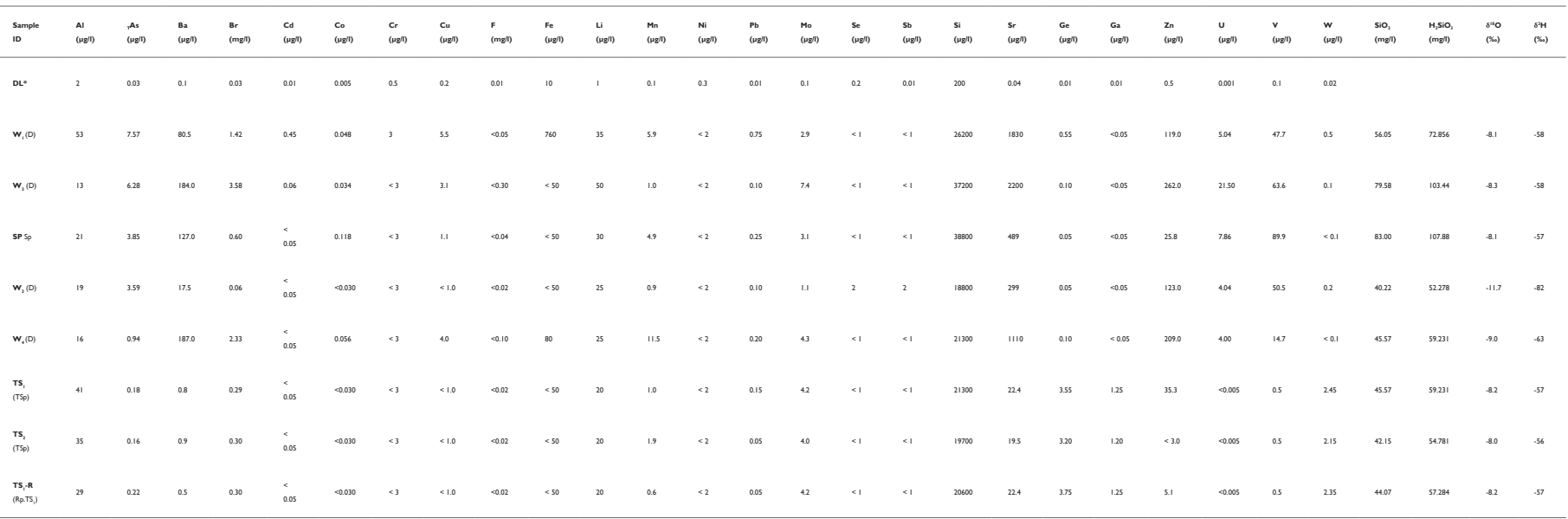

Table 3 Molar ratios of major and trace elements

\begin{tabular}{|c|c|c|c|c|c|c|c|c|c|c|c|c|c|}
\hline \multirow[t]{2}{*}{ Samples } & \multicolumn{13}{|c|}{ Molar ratio } \\
\hline & $\mathrm{Br} / \mathrm{Cl}$ & $\begin{array}{l}\mathrm{Srl} \\
\mathrm{Ca}\end{array}$ & $\begin{array}{l}\mathrm{Mg} / \\
\mathrm{Ca}\end{array}$ & $\begin{array}{l}\mathrm{Na} / \\
\mathrm{Cl}\end{array}$ & $\begin{array}{l}\mathrm{Ca} / \\
\mathrm{Na}\end{array}$ & $\mathrm{Mg} / \mathrm{Cl}$ & $\mathrm{Ca} / \mathrm{Cl}$ & $\mathrm{SO}_{4} / \mathrm{Cl}$ & $\begin{array}{l}\mathrm{Cl} / \\
\mathrm{HCO}_{3}+\mathrm{Cl}\end{array}$ & $\begin{array}{l}\mathrm{Na} / \\
\mathrm{Ca}+\mathrm{Mg}\end{array}$ & $\begin{array}{l}\mathrm{HCO}_{3} \mathrm{I} \\
\mathrm{Cl}\end{array}$ & $\begin{array}{l}\mathrm{Ca}+\mathrm{Mg} / \\
\mathrm{HCO}_{3}\end{array}$ & $\begin{array}{l}\Sigma \mathrm{CO}_{3} l \\
\text { silica }\end{array}$ \\
\hline$w_{1}$ & I.62E-03 & 7.54 & 0.59 & 0.67 & 0.38 & I.50E-0 I & $2.53 \mathrm{E}-0 \mathrm{I}$ & 4.39E-02 & 0.73 & 1.66 & 0.37 & 1.101856 & II.22846 \\
\hline$w_{2}$ & $1.20 \mathrm{E}-03$ & 3.69 & 1.14 & 0.53 & 0.35 & $2.08 \mathrm{E}-0 \mathrm{I}$ & $|.83 \mathrm{E}-0|$ & $5.46 \mathrm{E}-02$ & 0.81 & 1.35 & 0.23 & 1.719453 & 6.965992 \\
\hline $\mathrm{S}_{\mathrm{P}}$ & I.54E-03 & 2.72 & 0.86 & 1.28 & 0.33 & $3.63 \mathrm{E}-0 \mathrm{I}$ & $4.20 \mathrm{E}-0 \mathrm{I}$ & $3.84 \mathrm{E}-02$ & 0.38 & 1.64 & 1.65 & 0.475266 & 2.120156 \\
\hline $\mathrm{W}_{3}$ & $8.19 \mathrm{E}-04$ & 3.73 & 0.48 & 1.6 & 0.62 & $4.76 \mathrm{E}-0 \mathrm{I}$ & $9.99 \mathrm{E}-0 \mathrm{I}$ & I.25E-0। & 0.26 & 1.08 & 2.78 & 0.529507 & 2.330804 \\
\hline$W_{4}$ & I.72E-03 & 3.45 & 0.84 & 0.62 & 0.35 & I.82E-0| & $2.16 \mathrm{E}-0 \mid$ & $7.73 \mathrm{E}-02$ & 0.79 & 1.57 & 0.27 & 1.485217 & 5.526619 \\
\hline $\mathrm{TS}_{1}$ & $1.63 \mathrm{E}-03$ & 2.56 & 0.03 & 1.98 & 0.02 & $1.26 \mathrm{E}-03$ & 4.49E-02 & $1.25 \mathrm{E}-0 \mathrm{I}$ & 0.62 & 42.82 & 0.53 & 0.087233 & 1.296105 \\
\hline $\mathrm{TS}_{2}$ & $1.69 \mathrm{E}-03$ & 2.23 & 0.02 & 1.97 & 0.02 & $8.88 \mathrm{E}-04$ & 4.48E-02 & I.27E-0। & 0.56 & 43.17 & 0.7 & 0.065623 & I. 129737 \\
\hline$T S_{1}-R$ & I.70E-03 & 2.56 & 0.02 & 2.07 & 0.02 & $8.20 \mathrm{E}-04$ & $4.52 \mathrm{E}-02$ & I.26E-0I & 0.62 & 44.95 & 0.53 & 0.086393 & 1.238819 \\
\hline Sea water & $4.82 \mathrm{E}-03$ & 5.51 & 5.95 & 0.92 & 0.02 & I.IIE-0| & $1.86 \mathrm{E}-02$ & $5.04 \mathrm{E}-02$ & I & 7.06 & 0 & $42.58 \mid 25$ & \\
\hline
\end{tabular}

Table 4 Speciation of Fe(II), Fe(III) in sampled waters

\begin{tabular}{|c|c|c|c|c|c|c|c|c|c|}
\hline \multirow[t]{3}{*}{ Samples } & \multicolumn{9}{|c|}{ Fe speciation } \\
\hline & $\mathrm{Fe}(\mathrm{II})$ & & & & $\mathrm{Fe}(\mathrm{III})$ & & & & \\
\hline & $\mathrm{Fe}^{2+}$ & $\mathrm{FeHCO}_{3}$ & $\mathrm{FeCO}_{3}$ & $\mathrm{FeSO} 4$ & $\mathrm{Fe}^{3+}$ & $\mathrm{Fe}(\mathrm{OH})_{3}$ & $\mathrm{Fe}(\mathrm{OH})_{2+}$ & $\mathrm{Fe}(\mathrm{OH})_{4}^{-}$ & $\mathrm{FeCl}^{+}$ \\
\hline WI & I.05E-05 & $2.42 \mathrm{E}-06$ & $3.29 \mathrm{E}-07$ & 2.27E-07 & $9.56 \mathrm{E}-17$ & 2.19E-08 & I.46E-08 & $3.12 \mathrm{E}-10$ & $9.38 \mathrm{E}-08$ \\
\hline W2 & 3.10E-07 & I. $12 \mathrm{E}-07$ & 6. $10 \mathrm{E}-09$ & I.37E-08 & $5.76 \mathrm{E}-18$ & $8.14 \mathrm{E}-\mathrm{II}$ & $1.28 \mathrm{E}-10$ & $5.74 \mathrm{E}-13$ & $7.20 \mathrm{E}-09$ \\
\hline $\mathrm{SP}$ & $2.91 \mathrm{E}-07$ & I.40E-07 & I.15E-08 & $2.58 \mathrm{E}-09$ & $7.34 \mathrm{E}-2 \mathrm{I}$ & $2.94 \mathrm{E}-13$ & $3.51 \mathrm{IE}-13$ & $2.32 \mathrm{E}-15$ & $1.20 \mathrm{E}-09$ \\
\hline W3 & 3.39E-07 & $6.34 \mathrm{E}-08$ & I.06E-08 & 3.17E-09 & $3.62 \mathrm{E}-17$ & $1.96 \mathrm{E}-08$ & I.06E-08 & $3.02 \mathrm{E}-10$ & 3.17E- 10 \\
\hline W4 & I.09E-06 & $2.59 \mathrm{E}-07$ & $2.36 \mathrm{E}-08$ & 4.87E-08 & 4.67E-I8 & $2.40 \mathrm{E}-10$ & $2.53 \mathrm{E}-10$ & $2.29 \mathrm{E}-12$ & I.38E-08 \\
\hline TSI & $9.06 \mathrm{E}-08$ & $6.28 \mathrm{E}-09$ & I.58E-07 & $2.84 \mathrm{E}-09$ & $5.47 \mathrm{E}-24$ & $2.48 \mathrm{E}-08$ & $6.85 \mathrm{E}-1 \mathrm{I}$ & $7.20 \mathrm{E}-08$ & $2.08 \mathrm{E}-10$ \\
\hline TS2 & $1.05 \mathrm{E}-10$ & $8.85 \mathrm{E}-12$ & $3.08 \mathrm{E}-10$ & $2.98 \mathrm{E}-12$ & I.45E-23 & $9.97 \mathrm{E}-08$ & $2.34 \mathrm{E}-10$ & 3.47E-07 & $2.4 \mathrm{IE}-\mathrm{I} 3$ \\
\hline TSI-R & $9.06 \mathrm{E}-08$ & $6.30 \mathrm{E}-09$ & I.58E-07 & 2.84E-09 & 5.49E-24 & $2.48 \mathrm{E}-08$ & 6.84E-II & 7.19E-08 & $2.06 \mathrm{E}-10$ \\
\hline
\end{tabular}


Table 5 Saturation Index

\begin{tabular}{|c|c|c|c|c|c|c|c|c|c|c|c|c|c|c|c|c|c|c|c|c|c|c|}
\hline & $\begin{array}{l}\text { Al } \\
\text { bit } \\
\text { e }\end{array}$ & $\begin{array}{l}\text { Ca- } \\
\text { Mon } \\
\text { tm }\end{array}$ & $\begin{array}{l}\text { Ca } \\
\text { lcit } \\
\text { e }\end{array}$ & $\begin{array}{l}\text { Chal } \\
\text { cedo } \\
\text { ny }\end{array}$ & $\begin{array}{l}\mathrm{Fe} \\
(\mathrm{OH})_{3}\end{array}$ & $\begin{array}{l}\text { Gib } \\
\text { bsit } \\
\text { e }\end{array}$ & $\begin{array}{l}\text { Geo } \\
\text { thit } \\
\text { e }\end{array}$ & $\begin{array}{l}\mathrm{He} \\
\text { mati } \\
\text { te }\end{array}$ & Illite & $\begin{array}{l}\text { K- } \\
\text { Felds } \\
\text { par }\end{array}$ & $\begin{array}{l}\mathrm{K}- \\
\mathrm{Mi} \\
\mathrm{ca}\end{array}$ & $\begin{array}{l}\text { Kao } \\
\text { linit } \\
\text { e }\end{array}$ & $\begin{array}{l}\text { Qu } \\
\text { art } \\
z\end{array}$ & $\begin{array}{l}\text { sid } \\
\text { erit } \\
\text { e }\end{array}$ & $\begin{array}{l}\text { Dol } \\
\text { omi } \\
\text { te }\end{array}$ & $\begin{array}{l}\text { Ara } \\
\text { goni } \\
\text { te }\end{array}$ & $\begin{array}{l}\mathrm{Ba} \\
\text { rit } \\
\mathrm{e}\end{array}$ & $\begin{array}{l}\text { Ha } \\
\text { lit } \\
\text { e }\end{array}$ & $\begin{array}{l}\text { Chl } \\
\text { orit } \\
\text { e }\end{array}$ & $\begin{array}{l}\text { Chr } \\
\text { ysot } \\
\text { ile }\end{array}$ & $\begin{array}{l}\text { gyp } \\
\text { su } \\
\text { m }\end{array}$ & $\begin{array}{l}\text { Wit } \\
\text { heri } \\
\text { te }\end{array}$ \\
\hline WI & 0.05 & 4.66 & 0 & 0.21 & 0.11 & 1.68 & 5.94 & 13.89 & 3.77 & 1.01 & 9.97 & 5.48 & 0.65 & 0.02 & -0.1 & -0.14 & -0.18 & -5.79 & -2.86 & -5.26 & -1.91 & -3.59 \\
\hline W2 & 0.09 & 4.12 & 0.19 & 0.34 & -2.45 & 1.27 & 3.46 & 8.94 & 3.17 & 0.85 & 9 & 4.91 & 0.77 & -1.69 & 0.58 & 0.05 & 0.41 & -4.91 & -3.72 & -5.32 & -1.24 & -3.47 \\
\hline SP & 0.26 & 5.12 & -0.05 & 0.42 & -4.58 & 1.61 & 1.15 & 4.28 & 4.02 & 1.27 & 10.07 & 5.74 & 0.86 & -1.46 & -0.09 & -0.2 & -0.29 & -6.2 & -5.08 & -6.37 & -2.4 & -3.28 \\
\hline W3 & -1.49 & 2.96 & -0.47 & 0.06 & 0.05 & 1.2 & 5.89 & 13.78 & 2.08 & 0.11 & 8.12 & 4.22 & 0.5 & -1.47 & -1.14 & -0.61 & - & -7.52 & -5.99 & -6.6 & -2.74 & -4.24 \\
\hline W4 & -0.45 & 3.73 & -0.06 & 0.15 & -1.69 & 1.4 & 4.05 & 10.09 & 2.69 & 0.24 & 8.63 & 4.81 & 0.6 & -1.14 & -0.11 & -0.21 & 0.54 & -5.46 & -4.64 & -5.93 & -1.46 & -3.41 \\
\hline TSI & -1.65 & -2.47 & 0.32 & -0.16 & -0.49 & -1.04 & 5.72 & 13.5 & -2.39 & -1.36 & 2.22 & -0.74 & 0.24 & -0.24 & -0.67 & 0.18 & -2.28 & -6.68 & 1.71 & 0.35 & -3.32 & -3.87 \\
\hline TS2 & -1.51 & -2.35 & 0.48 & -0.16 & 0.5 & -1 & 6.49 & 15 & -2.19 & -1.14 & 2.49 & -0.63 & 0.26 & -2.98 & -0.55 & 0.34 & -2.14 & -6.67 & 1.01 & 0.08 & -3.34 & -3.6 \\
\hline TSI-R & -1.82 & -2.88 & 0.32 & -0.18 & -0.49 & -1.19 & 5.72 & 13.5 & -2.84 & -1.56 & 1.72 & -1.07 & 0.22 & -0.23 & -0.85 & 0.18 & -2.48 & -6.67 & 0.41 & -0.25 & -3.32 & -4.07 \\
\hline
\end{tabular}

\section{Geothermometry}

Subsurface thermal reservoir temperature is a crucial parameter in evaluating groundwater travelling depth. Both, silica and cation chemical geothermometers were applied to the groundwater samples. The geothermometer of amorphous silica and $\beta$-Cristobalite (Table 6) yielded temperatures which are below the measured temperature of groundwater samples. The quartz $\left(\mathrm{SiO}_{2}\right.$-Quartz, $\mathrm{SiO}_{2}$-Quartz adiabatic) solubility gives higher temperatures $\left(94^{\circ} \mathrm{C}\right.$ and $\left.127^{\circ} \mathrm{C}\right)$ comparing to Chalcedony and $\alpha, \beta$-Cristobalite $\left(-1 ; 99^{\circ} \mathrm{C}\right)$. Since silica solubility increases with temperature and $\mathrm{pH}$ increase, temperatures yielded by quartz adiabatic geothermometer for samples $\mathrm{TS}_{1}, \mathrm{TS}_{2}$ and $\mathrm{TS}_{1}-\mathrm{R}\left(99,96,98^{\circ} \mathrm{C}\right.$ respectively) are significant and may represent the conditions at depth (Table 6). Considering the possibility of dilution and mixing with local fresh-waters, the Na-K geothermometer can be used as well to estimate groundwater temperature in TS, $\mathrm{TS}_{2} \& \mathrm{TS}_{1}-\mathrm{R}$; indeed, values yielded by $\mathrm{Na}-\mathrm{K}^{42}\left(82,83,80^{\circ} \mathrm{C}\right.$ respectively) and $\mathrm{Na}-\mathrm{K}^{43}\left(103,104,101^{\circ} \mathrm{C}\right.$, respectively) are close to values given by quartz adiabatic geothermometer (Table 6). Based on the chemical analyses, the fingerprint of groundwater in samples $\mathrm{W}_{1}, \mathrm{~W}_{2}, \mathrm{~S}_{\mathrm{p}}, \mathrm{W}_{3} \& \mathrm{~W}_{4}$ has been notably impacted by the weathering of intermediate-mafic and metasedimentary rocks. At low temperature, mafic minerals are unstable and weather much more readily than felsic minerals. Therefore it is obvious that temperature will be less prominent than the one given for samples $\mathrm{TS}_{1}, \mathrm{TS}_{2} \& \mathrm{TS}_{1}-\mathrm{R}$. The Na-K-Ca geothermometer reflects equilibrium between $\mathrm{Na}$ and $\mathrm{K}$-feldspars, calcite or Ca-bearing minerals and geothermal waters. This geothermometer works well for waters enriched by $\mathrm{CO}_{2}$ and $\mathrm{Ca}$. The application of Na-K-Ca geothermometer in samples $\mathrm{W}_{1}, \mathrm{~S}_{\mathrm{p}} \& \mathrm{~W}_{3}$, has yielded values of 56,56 , and $58^{\circ} \mathrm{C}$ respectively, reflecting a relative shallow travelling depth. For samples $\mathrm{W}_{2}$ and $\mathrm{W}_{4}$, the use of Na-K-Ca geothermometer with $\mathrm{Mg}$ correction is more suitable; the $\mathrm{Mg}$ content in these waters is important, and the use of other geothermometers can give erroneous results. This geothermometer has yielded values of 37 and $45^{\circ} \mathrm{C}$ for $\mathrm{W}_{2}$ and $\mathrm{W}_{4}$, respectively. The $\mathrm{Na}-\mathrm{K}-\mathrm{Mg}^{1 / 2}$ triangular diagram ${ }^{43}$ provides an indication of the suitability of the waters for the application of solute geothermometers. ${ }^{44}$ This diagram (Figure 5) shows that most samples $\left(\mathrm{W}_{1}, \mathrm{~W}_{2}, \mathrm{~S}_{\mathrm{p}}, \mathrm{W}_{3}, \mathrm{~W}_{4}\right)$ plot in the immature waters field indicating the interaction water-rock along the flow path and that water did not reach ionic equilibrium. The $\mathrm{TS}_{1}, \mathrm{TS}_{2} \& \mathrm{TS}_{1}-\mathrm{R}$ samples present more suitability for geothermometry estimates and plot in the partially equilibrated field yielding temperatures between $80^{\circ} \mathrm{C}$ and $100^{\circ} \mathrm{C}$. The evidence of mixing in these geothermal waters can be inferred from the relationship between silica and carbonates; when a geothermal fluid reach boiling conditions, the carbon dioxide partitions into vapour phase producing a residual liquid which is depleted in carbonate. ${ }^{45}$ However, if dilution occurs before boiling and prevents degassing of the fluid, then the resultant discharge will retain the dissolved carbon dioxide and consequently have a high $\Sigma \mathrm{CO}_{3} / \mathrm{SiO}_{2}$ ratio. ${ }^{45}$ According to the $\Sigma \mathrm{CO}_{3} / \mathrm{SiO}_{2}$ ratio (1.5-2.2), groundwater in $\mathrm{TS}_{1}, \mathrm{TS}_{2} \& \mathrm{TS}_{1}-\mathrm{R}$ could be the result of mixing with no equilibrated water during an early stage of fluid ascent. The possibility of mixing of geothermal fluids with immature water has a negative effect on the reliability of silica geothermometers; in contrast, cation geothermometry is less sensitive to mixing and boiling processes, since it uses ratios rather than absolute abundances of the ions. ${ }^{46}$ Therefore, temperatures given by $\mathrm{Na}-\mathrm{K}^{43}$ geothermometer and $\mathrm{Na}-\mathrm{K}$ $\mathrm{Mg}^{1 / 2}$ ternary diagram may be more informative on the sub-surface temperature in $\mathrm{TS}_{1}, \mathrm{TS}_{2}$ (and $\mathrm{TS}_{1}-\mathrm{R}$ ).

Table 6 Cation and silica geothermometers

\begin{tabular}{|c|c|c|c|c|c|c|c|c|c|}
\hline $\begin{array}{l}\text { Sample } \\
\text { ID }\end{array}$ & $\begin{array}{c}\mathrm{SiO}_{2} \\
\text { Fournier } \\
(1977)\end{array}$ & $\begin{array}{c}\text { A } \\
\text { Cristobalite } \\
\text { Fournier } \\
(1977)\end{array}$ & $\begin{array}{c}\beta \\
\text { Cristobalite } \\
\text { Fournier } \\
(1977)\end{array}$ & $\begin{array}{l}\text { Chalcedony } \\
\text { Fournier } \\
(1977)\end{array}$ & $\begin{array}{c}\text { Quartz } \\
\text { adiabatic } \\
\text { Fournier } \\
(1977)\end{array}$ & $\begin{array}{c}\text { Na-K-Ca } \\
\text { Fournier \& } \\
\text { Truesdel }^{59}\end{array}$ & $\begin{array}{c}\text { Na-K-Ca } \\
\text { Mg } \\
\text { Fournier \& } \\
\text { Potter }^{42}\end{array}$ & $\begin{array}{c}\mathbf{N a} / \mathbf{K} \\
\text { Fournier \& } \\
\text { Potter }^{42}\end{array}$ & $\begin{array}{c}\mathbf{N a} / \mathbf{K} \\
\text { Giggenbach }^{43}\end{array}$ \\
\hline $\mathbf{w}_{1}$ & -9 & 57 & 10 & 78 & 107 & 56 & 56 & 149 & 168 \\
\hline $\mathbf{W}_{2}$ & 6 & 74 & 26 & 97 & 122 & 65 & 37 & 126 & 146 \\
\hline $\mathbf{W}_{3}$ & -22 & 42 & -4 & 61 & 94 & 58 & 58 & 270 & 282 \\
\hline
\end{tabular}




\begin{tabular}{|c|c|c|c|c|c|c|c|c|c|}
\hline $\begin{array}{l}\text { Sample } \\
\text { ID }\end{array}$ & $\begin{array}{c}\mathrm{SiO}_{2} \\
\text { Fournier } \\
\text { (1977) }\end{array}$ & $\begin{array}{c}\text { A } \\
\text { Cristobalite } \\
\text { Fournier } \\
(1977)\end{array}$ & $\begin{array}{c}\beta \\
\text { Cristobalite } \\
\text { Fournier } \\
(1977)\end{array}$ & $\begin{array}{l}\text { Chalcedony } \\
\text { Fournier } \\
\text { (1977) }\end{array}$ & $\begin{array}{c}\text { Quartz } \\
\text { adiabatic } \\
\text { Fournier } \\
(1977)\end{array}$ & $\begin{array}{c}\text { Na-K-Ca } \\
\text { Fournier \& } \\
\text { Truesdele }{ }^{59}\end{array}$ & $\begin{array}{c}\text { Na-K-Ca } \\
\text { Mg } \\
\text { Fournier \& } \\
\text { Potter }^{42}\end{array}$ & $\begin{array}{c}\mathbf{N a} / \mathbf{K} \\
\text { Fournier \& } \\
\text { Potter }\end{array}$ & $\begin{array}{c}\mathbf{N a} / \mathbf{K} \\
\text { Giggenbach }^{43}\end{array}$ \\
\hline$W_{4}$ & -18 & 47 & I & 67 & 99 & 45 & 45 & 109 & 130 \\
\hline TS, & -18 & 47 & 1 & 67 & 99 & 64 & 64 & 82 & 103 \\
\hline $\mathbf{T S}_{2}$ & -21 & 44 & -2 & 64 & 96 & 64 & 64 & 83 & 104 \\
\hline$T S_{1}-R$ & -19 & 46 & -1 & 66 & 98 & 64 & 64 & 80 & 101 \\
\hline
\end{tabular}

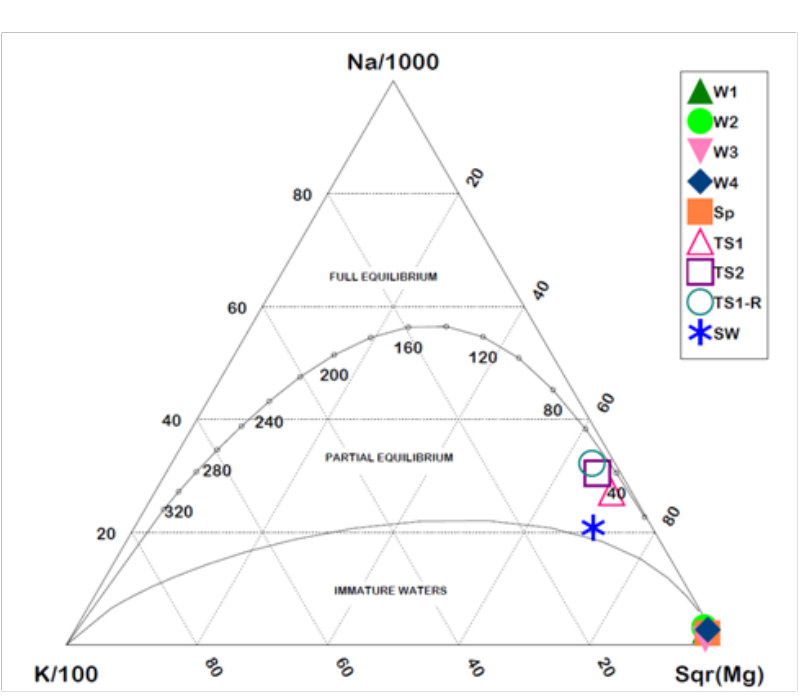

Figure 5 The $\mathrm{Na}-\mathrm{K}-\mathrm{Mg}^{1 / 2}$ diagram in $\mathrm{mg} / \mathrm{kg}^{43}$ as applied to sampled waters.

\section{Stable isotopes: oxygen I8-deuterium}

Stable and radioactive isotopes are natural tracers of water and solutes that complement geochemistry studies and provide an understanding of the origin, age, and evolution of groundwater. ${ }^{30}$ Stable isotopes of water $\left(\delta^{18} \mathrm{O}, \delta^{2} \mathrm{H}\right)$ have been used widely and successfully to distinguish between modern and palaeowaters, especially those recharged under colder conditions in the Late Pleistocene. ${ }^{9,47}$ In general, the isotopes dataset in Mexico are spatially and temporally deficient, with only two Global Networks for Isotopes in Precipitation (GNIP), the overall understanding of surface water-groundwater functioning over the country remains unexposed. The study of Wassenaar et al. ${ }^{48}$ has established a small-scale groundwater isoscape for Mexico, assuming that the stable isotopes composition of shallow travelled groundwater might serves as a useful proxy for integrating short term (5-10 years) precipitation infiltration input. Some outcome of this study was used to analyze obtained stables isotopes data with regard to local meteoric and shallow groundwater lines. Groundwater samples in $\mathrm{W}_{2}, \mathrm{~S}_{\mathrm{P}}, \mathrm{TS}_{1}, \mathrm{TS}_{2} \& \mathrm{TS}_{1-\mathrm{R}}($ Table 2) show isotopic values that reflect recharge in lower altitudes or under warmer conditions as compared to $\mathrm{W}_{3}$ and $\mathrm{W}_{4}$. Consequently, samples appear to belong to different groundwater flow systems, in which the recharge conditions are likely to be variable in time and space. In general all samples plot between the Mexican Meteoric Water line $\delta D=7.5\left(\delta^{18} O\right)+6.1 \%$, and the shallow travelling groundwater line $\delta D=7.9\left(\delta^{18} O\right)+6.4 \%$ ${ }^{48}$ (Figure 6A). Stable isotopes values are between -11.7 and $-8.0 \%$ for $\delta^{18} \mathrm{O}$; and -82 to $-56 \%$ for $\delta^{2} \mathrm{H}$ (Table 2); with the most depleted values in samples $\mathrm{W}_{3}$ and $\mathrm{W}_{4}$. In general, these values are depleted as compared to the tropical and summer falling rains which range between -6 to $0 \%{ }^{49-51}$. The low stable isotopes in Baja California were linked to tropical cyclones which produce rain with distinctly lower $\delta^{18} \mathrm{O}$ values $(<-6 \%)$ than other tropical rain systems. ${ }^{52}$ About $50 \%$ of the formed tropical cyclones are generating heavy rain $(\approx 400 \mathrm{~mm} / \mathrm{d})$ in the northern part of Baja California and along the pacific coast. ${ }^{53}$ The study of Jáuregui ${ }^{54}$ has emphasized that the western Mexican coast was exposed to a greater number of hurricanes than the coast of the Gulf of México. In some studies, little evidence has been detected regarding preservation of hurricane rain as groundwater. ${ }^{55}$ In karst areas where rapid recharge is likely to occur, the isotope signature of transient pulses of low $\delta^{18} \mathrm{O}$ water originating as hurricane rainwater can be detected in speleothem calcite. ${ }^{56}$ In groundwater, however, a hurricane pulse has little or no enduring effect. A possible exception may occur under unconfined conditions where values might reflect recharge of hurricane rainwater. ${ }^{55,57}$ Compared to groundwater sampled in $2007,{ }^{48}$ the isotopic signature of current samples reflect generally cooler temperatures conditions of recharge (Figure 6A). Depending on the nature of the lithological framework which is dominated by volcanic and meta-sedimentary rocks, and on the chemical patterns, which indicate a significant water-rock interaction during groundwater flow; the depleted stable isotopes values may advance new explanations regarding the relation between palaeo-climate, hurricanes effects, and groundwater isotopic signature in Northern Baja California. Further studies linking recent and palaeo-recharge processes as related to tropical cyclone events need to be conducted, as low $\delta^{2} \mathrm{H}$-values could indicate recharge during the deglaciation period, when the $\delta^{2} \mathrm{H}$ of the rain water was much more negative, probably by as much as $-50 \% .^{58}$ The $\mathrm{Cl}$ vs $\delta^{18} \mathrm{O}$ shows that depleted values of $\delta^{18} \mathrm{O}$ correspond to high $\left(\mathrm{W}_{2}, \mathrm{~W}_{4}\right)$ and low $\left(\mathrm{W}_{3}\right) \mathrm{Cl}$ content (Figure $\left.6 \mathrm{~B}\right)$. The chemical analyses, suggest an increase in groundwater residence time in $\mathrm{W}_{2}$ and $\mathrm{W}_{4}$; thus, the isotopic signature might confirm cold recharge conditions dating back to the late glacial period. More depleted $\delta^{18} \mathrm{O}$ and low $\mathrm{Cl}$ content in $\mathrm{W}_{3}$ may be the result of modern recharge from tropical cyclones. In general, integrated investigations must be conducted in the study region to further understand the occurrence of groundwater with different physico-chemical and isotopic signals.

\section{Groundwater flow systems determination}

Based on the physica-chemical, isotopic evidences and geothermometry; distinct flow conditions might be identified:

Group 1: (less mineralized thermal-waters $\left(\mathrm{Na}-\mathrm{Cl}-\mathrm{HCO}_{3}\right)$ ) is represented by $\mathrm{TS}_{1}, \mathrm{TS}_{2} \& \mathrm{TS} 1-\mathrm{R}$, these alkaline groundwaters are characterized by low TDS and high $\mathrm{pH}$. Their $\mathrm{Na} / \mathrm{Ca}+\mathrm{Mg}, \mathrm{Na} / \mathrm{Cl}$ and $\mathrm{HCO}_{3} / \mathrm{SiO}_{2}$ ratios reflect the importance of hydrolysis of Na-rich silicates. These waters are characterized by the presence of $\mathrm{Ga}, \mathrm{Ge}, \mathrm{Mo}$ 
and $\mathrm{W}$. The temperature in the reservoir was estimated at $80-100^{\circ} \mathrm{C}$ and the $\mathrm{HCO}_{3}$ concentration suggests chemical modifications with cooling during water upraise. The losses of $\mathrm{CO}_{2}$ during water ascent lower the solubility of $\mathrm{CaCO}_{3}$ to a greater amount; which explains the saturation of the samples with respect to calcite and aragonite. Despite the geological environment of the thermal waters which is characterized by volcanic (basalt, Mg-andesite, tonalite) and metasedimentary rocks; the low concentration of $\mathrm{Mg}$ indicates the limited access to Mg-naturally occurring rocks. The depleted $\mathrm{Sr}$ values (19-

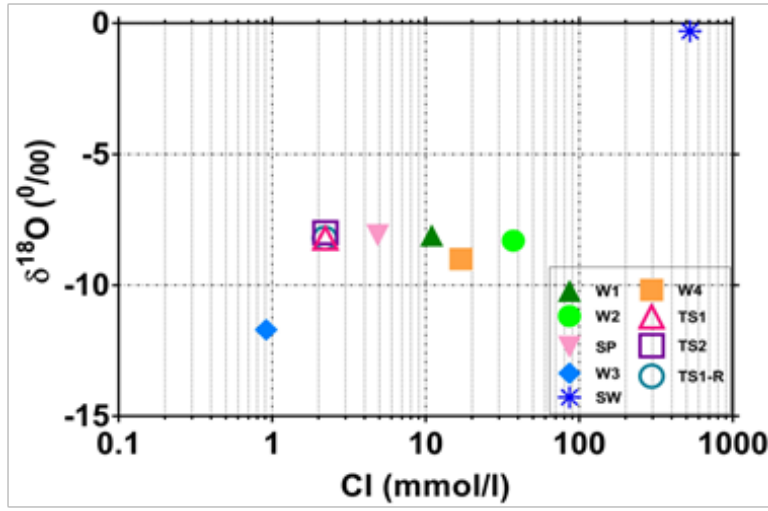

Figure 6 (A) $\delta^{18} \mathrm{O}-\delta^{2} \mathrm{H}$ plot for sampled groundwater. (B) $\delta^{18} \mathrm{O}$ vs $\mathrm{Cl}$ content.

Group 2: (brackish and mineralized groundwater ( $\mathrm{Na}-\mathrm{Ca}-\mathrm{Mg}$ Cl facies)) is represented by samples $\mathrm{W}_{1}, \mathrm{~W}_{2}$ and $\mathrm{W}_{4}$, these waters are enriched in minor and trace elements ( $\mathrm{As}, \mathrm{Sr}, \mathrm{Zn}, \mathrm{Pb} \& \mathrm{Cu})$. Groundwater temperature at depth was estimated at $37,45 \& 56^{\circ} \mathrm{C}$ for $\mathrm{W}_{2}, \mathrm{~W}_{4} \& \mathrm{~W}_{1}$, respectively. The temperature increase was accompanied by a mineralisation decrease; this may imply that water supplying $\mathrm{W}_{2}$ and $\mathrm{W}_{4}$ have being in contact with mafic minerals which preferentially weather at low temperature. The presence of mafic minerals was indicated by the importance of magnesium content in $\mathrm{W}_{2}$ and $\mathrm{W}_{4}$ (188.0 and $75.1 \mathrm{mg} / \mathrm{l}$, respectively). The $\mathrm{Mg} / \mathrm{Ca}$ ratio (Table 3) in $\mathrm{W}_{2}$ is greater than 0.9 suggesting that groundwater type is strongly affected by the weathering of Mg-rich silicates minerals. Whereas the $\mathrm{Mg} / \mathrm{Ca}$ ratio in $\mathrm{W}_{1}$ and $\mathrm{W}_{4}$ show association with carbonate rocks. The bicarbonate/silica ratios $(4-6<10)$ and TDS values show that groundwater in these samples is the result of silicate and carbonate weathering. The high levels of $\mathrm{Sr}$ and $\mathrm{Na}$ show evidence of an extensive water-rock interaction. Based on geothermometry, mineralisation, and chemical water age tracers $\left({ }_{\mathrm{T}} \mathrm{As}, \mathrm{Sr}, \mathrm{Li}, \mathrm{Cl}, \mathrm{U}\right)$ these samples reflect the occurrence of long residence groundwater, and in term of flow systems this group could be classified as intermediate flow.

Group 3: (fresh and peripheral groundwater (Ca-Na-MG-HCO$C l)$ ) is represented by $\mathrm{S}_{\mathrm{p}}$ and $\mathrm{W}_{3}$, these waters are very distinctive; $\mathrm{S}_{\mathrm{P}}$ water was sampled from a spring at $577 \mathrm{~m}$ asl of altitude; it has a TDS of $997.49 \mathrm{mg} / \mathrm{l}$ and it presents an important $\mathrm{HCO}_{3}$ concentration $\left(\mathrm{HCO}_{3} / \mathrm{Cl} \approx 1.64\right)$; the $\mathrm{Na} / \mathrm{Ca}$ ratio suggests cation-exchange. Regarding minor and trace elements, $\mathrm{S}_{\mathrm{p}}$ sample shows the importance of $\mathrm{As}, \mathrm{Ba}, \mathrm{Co}, \mathrm{Pb}, \mathrm{V} \& \mathrm{U}$ (Table 2), suggesting a significant water-rock interaction. The temperature at depth was estimated at $56^{\circ} \mathrm{C}$ indicating that waters supplying this spring were travelling in a relatively shallow depth implying a local flow system. Groundwater in $\mathrm{W}_{3}$ represents younger characteristics; this is reflected in $\mathrm{HCO}_{3} / \mathrm{Cl}$ and $\mathrm{Ca} / \mathrm{Na}$ molar ratios $(2.78$, and 0.62 , respectively) and in low value of TDS $(310.23 \mathrm{mg} / 1)$. The depth to the water-table was estimated to 78
$22.4 \mu \mathrm{g} / \mathrm{l})$ could indicate a low contact with sedimentary carbonate rocks. Saturation with respect to silicates minerals (K-mica, chlorite, chrysotile and talc), and ferruginous products (geothite and hematite) could be originated from the hydrothermal weathering of amphibolebiotite forming the metamorphic rocks. The geothermometry and physico-chemical characteristics (Li,pH,T,TDS) of the thermal springs may reflect deep and rapid flow system. The nature of this flow is propose as regional.

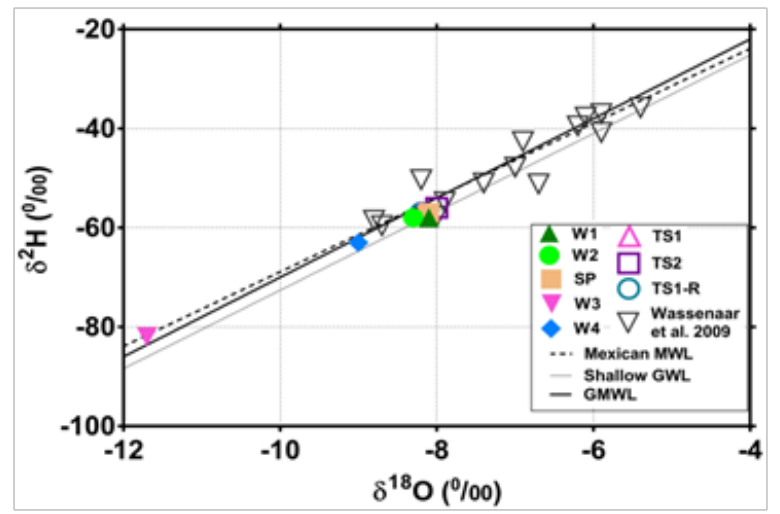

$\mathrm{m}$, thus, this water could represent recharge-transit conditions. In the absence of clear understanding of the history of groundwater isotopic signature in northern Baja California, the depletion of stable isotopes in $\mathrm{W}_{3}$ may be related to groundwater recharge by recent hurricanes.

\section{Conclusion}

Protected areas of Northern Baja California may be subjected to natural and human stress; thus any sustainable development of the area has to consider the involvement of groundwater as an ecological agent. This work was conducted in order to determine the groundwater flow systems characterizing the protected area of Valle de Los Cirios. Results acknowledged the presence of different groundwater flow systems, three groundwater groups were differentiated. These groups have shown the presence of water with relatively long, moderate and short residence time. The groundwater geothermometry has revealed different depths and conditions of flow with Grp1 representing a deep and rapid flow through fractured igneous volcanic and metamorphic rocks; fresh groundwater flow of Grp3 appears to travel across sedimentary and volcanic sequences in relatively shallow conditions, and groundwater in Grp2 representing more evolved travelling conditions. The dominance of alkaline and shallow brackish groundwater types appears to trigger the preferential growth of desertic vegetation which might be vulnerable to a regional lowering of groundwater table. Additional groundwater studies required to be conducted in the region in order to generate a 3D groundwater flow model, with a further application of the groundwater flow systems, and links the zone of recharge with those of discharge and their related soil and vegetation.

\section{Acknowledgments}

The authors wish to thank the personnel of the Dirección del Área de Protección de Flora y Fauna (APFF) Valle de los Cirios, for the invitation to conduct this work, and for providing financial support 
for the field activities, and facilities to access the sampling sites. The authors would like also to thank local dwellers and ranchers for their cooperation and authorizing to sample their domestic wells. This study was conducted in collaboration with the Direction of APFF Valle de Los Círios, the Research Centre for Biodiversity and Conservation of the Universidad Autónoma del Estado de Morelos (UAEM), and the Universidad Nacional Autónoma de México (UNAM).

\section{Conflict of interest}

None.

\section{References}

1. Riemann H, Ezcurra E. Plant endemism and natural protected areas in the peninsula of Baja California, Mexico. Biological Conservation. 2005;122(1):141-150.

2. Bernaldez FG, Rey BJM, Levassor C, et al. Landscape ecology of uncultivated lowlands in central Spain. Landscape Ecology. 1989;3(1):318.

3. Webb RH, Leake SA. Ground-water surface-water interactions and longterm change in riverine riparian vegetation in the southwestern United States. Journal of Hydrology. 2006;320(3-46):302-323.

4. Ouysse S. Simulation of surface water and groundwater flows in the High and Middle Draa sub-basins. Morocco: Cadi Ayyad University; 2012.

5. Mádl SJ, Simon S, Tóth J. Hydrodynaic interaction between gravitydriven and over-pressured groundwater flow and its consequences on soil and wetland calinisation, In: Ribeiro L, et al. editors. Groundwater and Ecosystems, USA: Taylor and Francis Group; 2013. p. 1-358.

6. Tóth J. A theoretical analysis of groundwater flow in small drainage basins. J Geophys Res. 1963;68(16):4795-4812.

7. Tóth J. Gravitational Systems of Groundwater Flow Theory, Evaluation, Utilization. UK: Cambridge University Press; 2009. p. 1-310.

8. Elliot T, Andrews JN, Edmunds WM. Hydrochemical trends, palaeorecharge and groundwater ages in the fissured Chalk aquifer of the London and Berkshire Basins, UK. Applied Geochemistry. 1999;14(13):333-363.

9. Edmunds WM, Smedley P. Residence time indicators in groundwater: the East Midlands Triassic sandstone aquifer. Applied Geochemistry. 2000;15(6):737-752.

10. Carrillo RJJ, Cardona A, Edmunds WM. Use of abstraction regime and knowledge of hydrogeological conditions to control high fluoride concentration in abstracted groundwater: basin of San Luis Potosi, Mexico. Journal of Hydrology. 2002;261:24-47.

11. Carrillo RJJ, Cardona A. Groundwater Flow System Response in Thick Aquifer Units: Theory and Practice in Mexico, In: Carrillo R \& Ortega G (Eds.), Groundwater Flow Understanding: From Local to Regional Scale. Mexico: Taylor \& Francis Group; 2008. p. 1-70.

12. Shapiro A. The challenge of interpreting environmental tracer concentrations in fractured rock and carbonate aquifers. Hydrogeology Journal. 2011;19(1):9-12.

13. García E. Modificaciones al sistema de clasificación climática de Köppen. México: Universidad Nacional Autónoma de México; 1988. p. 1-98.

14. Martin BA. The geological foundations of the gulf of California region. Conservation Science in Mexico's Northwest. USA: Ecosystem Status and Trend in the Gulf of California; 2014. p. 67-94.

15. Gastil RG, Phillips RP, Allison GC. Reconnaissance Geology of the State of Baja California. USA: Geological Society of America; 1975. p. 1-170.
16. Silver LT, Chappell BW. The Peninsular Ranges batholith: An insight into the evolution of the Cordilleran batholiths of southwestern North America. Trans Royal Society of Edinburgh. 1988;79(2-3):105-121.

17. Johnson SE, Tate MC, Fanning CM. New geologic mapping and SHRIMP U-Pb data in the Peninsuar Ranges batholith, Baja California, Mexico Evidence of a suture?. Geology. 1999(a);27(8):743-746.

18. Johnson S, Paterson S, Fletcher J, et al. Tectonic Evolution of Northwestern México and the Southwestern USA. USA: Geological Society of America; 2003.

19. Todd VR, Erskine BG, Morton DM. Metamorphic and tectonic evolution of the northern Peninsular Ranges batholith, southern California. In: Ernst WG editor. Metamorphism and crustal evolution of the western United States, USA: Englewood Cliffs, 1988. p. 894-937.

20. Walawender MJ, Gastil RG, Clinkenbeard JP, et al. Origin and evolution of La Posta-type plutons, eastern Peninsular Ranges batholith, southern and Baja California. In: Anderson JL editor. The nature and origin of Cordilleran magmatism: Boulder, Colorado, USA: Geological Society of America; 1990. p. 1-18.

21. Gastil R, Miller R, Anderson P, et al. The relation between the Paleozoic strata on opposite sides of the Gulf of California. In: Perez SE, Jacques AC editors. Studies of Snran geology, USA: Geological Society of America Special Paper 254; 1991. p. 7-17.

22. Torres CX, Delgado ALA, Espinosa CJM, et al. Análisis geológico y aeromagnético de las concentraciones anómalas de Fe en el plutón San Jerónimo en el Cinturón Batolítico Peninsular, Baja California, México. Boletín Sociedad Geológica Mexicana. 2011;63(3): 487-501.

23. Beal CH. Reconnaissance of the geology and oil possibilities of Baja California. Mexico: Geol Soc America Mem; 1948. p. 1-138.

24. Mina UF. Bosquejo geológico del Territorio Sur de la Baja California. Asoc Mexicana Geólogos Petroleros Bol. 1957;9:139-269

25. Tóth J. Groundwater as a geologic agent: an overview of the causes, processes, and manifestations. Hydrogeol J. 1999;7(1):1-14.

26. Wehncke EV, Rebman J, López MX, et al. Sierra de la Libertad: A Major Transition between Two Desert Regions In Baja California, Mexico. Botanical Sciences. 2012;90(3):239-261.

27. Parkhurst DL, Appelo CAJ. User's guide to PHREEQC (version 2): a computer program for speciation, batch reaction, one-dimensional transport, and inverse geochemical calculations. US Geological Survey: Earth Science Information Center, 1999, p. 1-326.

28. Prol LRM, Canet C, Torres VMA, et al. Vent fluid chemistry in Bahia Concepcion coastal submarine hydrothermal system, Baja California Sur, Mexico. Journal of Volcanology and Geothermal Research. 2004;137(4):311-328.

29. Han DM, Liang X, Jin MG, et al. Evaluation of groundwater hydrochemical characteristics and mixing behavior in the Daying and Qicun geothermal systems, Xinzhou Basin. Journal of Volcanology and Geothermal Research. 2010;189(1-2):92-104.

30. Clark I. Groundwater Geochemistry and Isotopes. Australia: CRC Press, 2015. p. 1-456.

31. Back W, Letolle R. Symposium on Geochemistry of Groundwater. USA: Elsevier Sc Pub Co Amsterdam; 1982. p. 1-368.

32. Edmond JM, Palmer MR, Measures CI, et al. The fluvial geochemistry and denudation rate of the Guayana Shield in Venezuela, Colombia, and Brazil. Geochimica et Cosmochimica Acta. 2015;59(16):3301-3325.

33. Meybeck M. Composition chimique des ruisseaux non pollués de France. Sci Geol Bull. 1986;39:3-77. 
34. Richter BC, Kreitler CW. Geochemical Techniques for Identifying Sources of Ground-Water Salinization. USA: CRC Press Inc; 1993. p. $1-272$.

35. Edmunds WM. Bromine geochemistry of British groundwaters. Mineralogical Magazine. 1996;60:275-284.

36. Martin JB. Nonconservative behavior of $\mathrm{Br} 2 / \mathrm{Cl} 2$ ratios during alteration of volcaniclastic sediments. Geochimica et Cosmochimica Acta. 1999;63(3/4):383-391.

37. Hayes KF, Papelis C, Leckie JO. Modeling ionic strength effects on anion adsorption at hydrous oxide/solution interfaces. Journal of Colloid and Interface Science 1988;125(2):717-726.

38. Boyle RW. Geochemical Prospecting for Thorium and Uranium Deposits USA: Developments in Economic Geology; 1982. p. 1-498.

39. Wunsch DR. High barium concentrations in ground water in eastern Kentucky: Proceedings for the National Water Well Conference. USA Ground Water Geochemistry; 1988. p. 175-197.

40. Gilkeson R, Cartwright K, Cowart JB, et al. Hydrogeological and Geochemical studies of selected Natural Radioisotopes and Barium in Groundwater in Illinois. Final Technical Report to Bureau of Reclamation, Department of the Interior USA; 1983. p. 1-104.

41. Johannesson KH, Dave HB, Mohajerin TJ, et al. Controls on tungsten concentrations in groundwater flow systems: The role of adsorption, aquifer sediment $\mathrm{Fe}(\mathrm{III})$ oxide/oxyhydroxide content, and thiotungstate formation. Chemical Geology. 2013;351:76-94.

42. Fournier RO, Potter RW. Magnesium correction to the Na-K-Ca chemica geothermometer. Geochim Cosmochim Acta. 1979;43:1-24.

43. Giggenbach WF. Geothermal solute equilibria. Derivation of $\mathrm{Na}-\mathrm{K}-\mathrm{Mg}$ Ca geoindicators. Geochim Cosmochim Acta. 1988;52(12):2749-2765.

44. Pürschel M, Gloaguen R, Stadler S. Geothermal activities in the Main Ethiopian Rift: Hydrogeochemical characterization of geothermal waters and geothermometry applications (Dofan-Fantale, Gergede-Sodere, Aluto-Langano). Geothermic. 2013;47:1-12.

45. Nicholson K. Geothermal Fluids: Chemistry and Exploration Techniques. USA: Springer; 1993. p.1-225

46. Gendenjamts O. Interpretation of geochemical composition of geothermal fluids from Árskógsströnd, Dalvík, and Hrísey, N-Iceland and in the Khangai area, Mongolia. USA: Geothermal training programme; 2003. p. $219-252$
47. Darling WG, Edmunds WM, Smedley P. Isotopic evidence for palaeowaters in the British Isles. Appl Geochem 1997;12(6):813-829.

48. Wassenaar LI, Van WSL, Larson K, et al. A groundwater isoscape $(\delta \mathrm{D}, \delta 18 \mathrm{O})$ for Mexico 2009. Journal of Geochemical Exploration 2009;102(3):123-136.

49. DansgaardW.Stableisotopes in precipitation. Tellus. 1964;16(4):436-468

50. Lawrence JR, White JWC. The elusive climate signal in the isotopic composition of precipitation. In: Taylor HP, editor. Stable isotope geochemistry: a tribute to Samuel Epstein. Geochem Soc Spec Publ No. 1991;3:1-18.

51. Lawrence JR, Gedzelman SD. Low stable isotope ratios of tropical cyclone rains. Geophysical Research Letters. 1996;23(5)527-530.

52. Miller DL. A Tree-Ring Oxygen Isotope Record of Tropical Cyclone Activity, Moisture Stress, and Long-term Climate Oscillations for the Southeastern US. Thesis: The University of Tennessee; 2005. p. 1-182.

53. Romero VE, Zaytsev O, Morales PR. Tropical cyclone statistics in the Northeastern Pacific. Atmósfera. 2007;20(2):197-213

54. Jauregui E. Vulnerability to tropical cyclones in the northwest coast of México. México: Instituto de Geografía UNAM; 1981. p. 1-14

55. Eastoe CJ, Hess G, Mahieux S. Identifying Recharge from Tropical Cyclonic Storms, Baja California Sur, Mexico. Groundwater. 2015;53(1):133-138.

56. Frappier AB. Interpreting stable isotopes in tropical stalagmites; masking of inter-annual climate proxy signals by residual tropical cyclone water from Hurricane Mitch. Abstracts with Programs - Geological Society of America. 2007;39(1):1-192.

57. Fahlquist L, Ardis AF. Quality of water in the Trinity and Edwards aquifers, south-central Texas, 1996-1998. USA: Scientific Investigations Report 2004-5201; 2004. p. 1-23.

58. Ji YW, Zhong HP. Isotope and Geochemical techniques Applied to Geothermal Investigations. USA: IAEA; 1995. p. 1-268.

59. Fournier RO, Truesdell AH. An empirical Na-K-Ca geothermometer for natural waters. Geochim Cosmochim Acta 1973;37(5):1255-1275. 